Article

\title{
Experimental Modeling of Noble and Chalcophile Elements Fractionation during Solidification of $\mathrm{Cu}-\mathrm{Fe}-\mathrm{Ni}-\mathrm{S}$ Melt
}

\author{
Elena Sinyakova ${ }^{1, *}$, Victor Kosyakov ${ }^{2}$, Galina Palyanova ${ }^{1,3} \mathbb{D}$ and Nikolay Karmanov ${ }^{1}$ \\ 1 VS Sobolev Institute of Geology and Mineralogy, Siberian Branch of the Russian Academy of Sciences, \\ pr. Akademika Koptyuga 3, 630090 Novosibirsk, Russia \\ 2 Nikolaev Institute of Inorganic Chemistry, Siberian Branch of the Russian Academy of Sciences, \\ Lavrent'ev ave. 3, 630090 Novosibirsk, Russia \\ 3 Department of geology and geophysics, Novosibirsk State University, Pirogova str., 2, \\ 630090 Novosibirsk, Russia \\ * Correspondence: efsin@igm.nsc.ru; Tel.: +7-383-373-05-26
}

Received: 18 July 2019; Accepted: 29 August 2019; Published: 31 August 2019

\begin{abstract}
We carried out a directed crystallization of a melt of the following composition (in mol. \%): Fe 31.79, Cu 15.94, Ni 1.70, S 50.20, Sn 0.05, As 0.04, Pt, Pd, Rh, Ru, Ag, Au, Se, Te, Bi, and Sb by 0.03 . The obtained cylindrical sample consisted of monosulfide solid solution (mss), nonstoichometric isocubanite $\left(i c b^{*}\right)$, and three modifications of intermediate solid solution $\left(i s s_{1}, i s s_{2}, i s s_{3}\right)$ crystallized from the melt. The simultaneous formation of two types of liquids separated during cooling of the parent sulfide melt was revealed. In the first, concentrations of noble metals associated with $\mathrm{Bi}, \mathrm{Sb}$, and Te were found. The second is related to $\mathrm{Cu}$ and was found to contain a large amount of $\mathrm{S}$ in addition to $\mathrm{Bi}$ and $\mathrm{Sb}$. We established the main types of inclusions formed during fractional crystallization of Pt-bearing sulfide melt. It was shown that noble metals are concentrated in inclusions in the form of $\mathrm{RuS}_{2}, \mathrm{PdTe}_{2},(\mathrm{Pt}, \mathrm{Pd}) \mathrm{Te}_{2}, \mathrm{PtRhAsS}$, and $\mathrm{Ag}_{2} \mathrm{Se}$, doped with $\mathrm{Ag}, \mathrm{Cu}$, and $\mathrm{Pd}$, in $m s s$ and in the form of $\mathrm{PtAs}_{2}$; Au-doped with $\mathrm{Ag}, \mathrm{Cu}$, and $\mathrm{Pd} ; \mathrm{Ag}_{2} \mathrm{Te}$; and $\mathrm{Pd}(\mathrm{Bi}, \mathrm{Sb})_{x} \mathrm{Te}_{1-x}$ in $i c b^{*}$ and iss. As solid solutions in the base metal sulfides, $\mathrm{Rh}$ is present in $m s s, \mathrm{Sn}$ in iss.
\end{abstract}

Keywords: Cu-Fe-Ni-S system; platinum-group elements; Au; Ag; metalloid elements; fractional crystallization; drop-shaped inclusions

\section{Introduction}

Massive ore bodies of copper-nickel deposits are formed from zones with various phases and chemical compositions. When passing from one zone to another, their phase and chemical composition changes abruptly [1-4]. Such a structure suggests that they resulted from fractional crystallization of magmatic sulfide melt [5-9]. For the Noril'sk deposit, no less than two main types of zonality are observed, in one of which the fugacity of sulfur increases, and in the second, it decreases $[1,2,10]$. The possibility of several types of zonality is shown in the experiments on directed crystallization of Cu-Fe-Ni-sulfide melts [11-19] (The terms "directed crystallization" and "fractional crystallization" describe the process of gradual solidification of the melt in the absence of mixing in the solid ingot and complete or partial mixing in the melt. From the physicochemical point of view, when modeling the solidification of a cylindrical ingot in laboratory or industrial equipment, the term "directed crystallization" is more acceptable).

The Noril'sk ores contain a wide variety of geochemically important trace elements. The most significant are noble metals ( $\mathrm{Pt}, \mathrm{Pd}, \mathrm{Rh}, \mathrm{Ru}, \mathrm{Ir}, \mathrm{Au}, \mathrm{Ag})$, heavy metals $(\mathrm{Zn}, \mathrm{Sn}, \mathrm{Pb})$, and anion-forming elements (As, Sb, Bi, Se, Te). Noble metals can enter the lattice of the main ore-forming minerals or form 
independent phases both with the main elements and with other trace elements. Since the Noril'sk ores are an important industrial source of the platinum group elements (PGE), intense research on the regularities of Ag-Au-PGE mineralization has been carried out [1-4,20-24].

Most geologists assume that magmatic sulfide liquids are the source of PGE [2,4,10,25]. In [24], a hypothesis is presented about the pneumatolytic genesis of compounds of noble metals. Both hypotheses are based on the results of geochemical observations and on experimental data $[1,2,4,10,17-19,26-35]$. Fundamental knowledge about the behavior of noble metals is contained primarily in the phase diagram of the systems related to this problem (see the review in [36-41]). Useful information is contained in experimental data on the composition and structure of samples obtained by prolonged isothermal annealing of partially crystallized samples and further quenching to room temperature [30-32,36-41]. For example, in [36], diagrams of the following systems were described: Pd-Fe-S, Pd-Ni-S, Pd-Cu-S, Pd-Pt-S, Fe-Pt-S, Pt-Fe-As-S, Pt-Pd-As-S, Pd-Ni-As, Pd-Sb-Te, Pt-Pd-Sb, Pd-Bi-Te, Pd-Pt-Sb, and so on. In this case, the composition of the samples is chosen by the experimenter. By contrast, in our works, we studied samples obtained by directed crystallization of melts of a given composition [11-19]. Usually, this method is applied in the case of gradual solidification of a cylindrical sample from one end to another. In this process, the melt is separated from the crystallized mass by a single interface- - the crystallization front. The difference in the compositions of the melt and coexisting solid phases leads to fractionation of the components during crystallization, i.e., to a gradual change in the compositions of the melt and solid phases. With a particular melt composition, a phase reaction can run at the crystallization front, in the course of which some of the phases produced from the melt can disappear and new phases can appear. Therefore, crystallization of a multicomponent melt usually produces a sample consisting of several zones with different phase compositions. A similar zoning is also observed in sulfide orebodies.

Below, we describe the main advantage of the directional crystallization method in a quasi-equilibrium regime to study the behavior of elements during the fractional crystallization of sulfide melts. First, an experiment with this process permits a large set of data on the equilibrium phase diagram of a multicomponent (the main and minor elements) system to be obtained. Second, the experiment helps to study the behavior of the main and minor elements both during crystallization and during a subsequent cooling of the crystallized sample. Third, with this method, it is possible to determine the sequence of phase formation during fractional crystallization, which is rather difficult to do using the results of the study of annealed samples.

During the directed crystallization of a sample of a given composition, the "chemical system itself chooses" the crystallization path. This path in the quasi-equilibrium process uniquely depends on the composition of the initial sample and the liquid-solid diagram. This method can be used for systems with an arbitrary number of components, and its results, for constructing both simple and complex diagrams. In experiments on isothermal annealing, the set of quenched samples is studied, the composition of which is determined by the experimenter.

The crystallized zone of the ingot imitates the structure of the ore body. The ingot is used for preparing genetically related samples, the composition of which is determined by the rules of directed crystallization. Thus, we simulated the formation of pyrrhotite-cubanite, pentlandite-bornite, and other mineral varieties of massive ore bodies from the Noril'sk deposit and also studied the behavior of ensembles of minor elements [11-14,16-18,33,42]. In particular, Cu-Fe-Ni sulfide melts with the following ensembles of impurities were crystallized by this method: Pt, Pd, Rh, Ru, Ir, $\mathrm{Au}, \mathrm{Ag}$ [42], Pt, Pd, Rh, Ru, Ir, Au, Ag, Co, As [17], Pt, Pd, Au, As, Te, Bi, and Sn [18,19,33]. The distribution curves of components were constructed, and phase and chemical compositions of inclusions containing PGE (drop-shaped included) were analyzed.

Results of the geochemical and experimental studies described in the literature are insufficient for the verification of two hypotheses (magmatic and pneumatolytic) about the impurity mineralization of the Noril'sk deposits. To understand the role of these processes, additional results are required. In this paper, we carried out experimental modeling of fractionation crystallization of melt formed from $\mathrm{Cu}$, $\mathrm{Ni}, \mathrm{S}, \mathrm{Pt}, \mathrm{Pd}, \mathrm{Rh}, \mathrm{Ru}, \mathrm{Ag}$, Au, As, Se, Sn, Te, Bi, and Sb, in a closed system, which corresponds to the 
magmatogenic mechanism of formation of solid ore bodies. New data on the evolution of the studied physicochemical system in this process were obtained.

\section{Experimental}

\subsection{Sample Preparation}

We carried out a directed crystallization of a melt of the following composition (in mol. \%): Fe 31.79, Cu 15.94, Ni 1.70, S 50.20, Sn 0.05, As 0.04, Pt, Pd, Rh, Ru, Ag, Au, Se, Te, Bi, and Sb by 0.03. This composition imitates the composition of representative ore samples from the Octyabr'sky mine [26]. The initial sample, $20 \mathrm{~g}$ in weight, was prepared from sulfur (99.9999\%), additionally purified by vacuum distillation, and other elements with a purity grade of $99.99 \%$. The mixture was heated at a rate of about $100 \mathrm{deg} / \mathrm{day}$ up to $700{ }^{\circ} \mathrm{C}$ and then for a day up to $1050{ }^{\circ} \mathrm{C}$. The melted sample was kept for 2 days and then quenched in a switched-off furnace. After dry grinding, the powdered sample was replaced into the ampoule, with an $8 \mathrm{~mm}$ diameter and conical end, which was then evacuated and sealed. A scheme showing the experimental apparatus and the procedure of preparing the sample were described in detail in [18]. Crystallization was performed using the Bridgman method in a vertical two-zoned furnace, with a diaphragm, by lowering the ampoule with a homogeneous melt from the hot zone to the cold zone at a rate of $2.3 \times 10^{-8} \mathrm{~m} / \mathrm{s}$. This regime provided quasi-equilibrium conditions for directed crystallization. The temperature in the lower end of the quartz container was $1025^{\circ} \mathrm{C}$ at the beginning of crystallization, and $825^{\circ} \mathrm{C}$ at the end. After crystallization, the ampoule was cooled in air at an average rate of $\sim 100 \mathrm{deg} / \mathrm{min}$.

\subsection{Investigation of Crystallized Samples}

The obtained ingot, about $120 \mathrm{~mm}$ in length and $8 \mathrm{~mm}$ in diameter, was cut perpendicular to the longitudinal axis into 19 parts. These were weighed and the fraction of crystallized melt, $g$, was determined. Seventeen fragments were used to prepare polished sections, which were studied by microscopic and chemical analysis.

Results of the sample study showed that the crystallization front was flat, perpendicular to the axis of the ingot, and homogenous in the averaged chemical composition of components. The average chemical composition of the ingot and inclusions, as well as the local composition phases, were measured using energy dispersion spectrometry (SEM-EDS) on a high-resolution microscope MIRA 3 LMU (Tescan Orsay Holding, Brno-Kohoutovice, Czech Republic), combined with X-ray microanalysis systems INCA Energy 450+ X-Max 80 and INCA Wave 500 (Oxford Instruments Nanoanalysis Ltd, Abingdon, UK) in the Analytical Center for multi-elemental and isotope research SB RAS (analyst N.S. Karmanov, Novosibirsk, Russia). For the analysis, K-series (S, Fe, Cu, Ni) and L-series (Pt, Pd, Rh, Ru, $\mathrm{Au}, \mathrm{Ag}, \mathrm{As}, \mathrm{Te}, \mathrm{Se}, \mathrm{Bi}, \mathrm{Sb}, \mathrm{Sn}$ ) of $\mathrm{X}$-ray radiation were used. As the standards, we used $\mathrm{FeS}_{2}$ (on S), $\mathrm{PbTe}$ (on Te), $\mathrm{PtAs}_{2}$ (on As), and the pure elements of $\mathrm{Fe}, \mathrm{Ni}, \mathrm{Cu}, \mathrm{Se}, \mathrm{Ru}, \mathrm{Rh}, \mathrm{Pd}, \mathrm{Ag}, \mathrm{Sn}, \mathrm{Sb}, \mathrm{Pt}, \mathrm{Au}, \mathrm{and}$ Bi. Phases smaller than $5 \mu \mathrm{m}$ were analyzed using a point probe, and larger phases were analyzed in a small raster mode with the size of the scanned area up to $100 \mu \mathrm{m}^{2}$. The measurements were conducted at an accelerating voltage of $20 \mathrm{kV}$, electron beam current of $1.5 \mathrm{nA}$, and live acquisition time of spectra of $30 \mathrm{~s}$. Under these conditions of analysis, the limit of detection (LOD) was 0.4 to $0.5 \mathrm{wt}$. \% for Pt, Au, and $\mathrm{Bi}$, and 0.1 to $0.2 \mathrm{wt}$. \% for the others. The error in determining was no more than 1 to 1.5 relation $\%$ for the major components and 2 to 5 relation \% for minor. To estimate the average composition of multi-phase areas, we used the total spectrum obtained by scanning the areas of up to $1.5 \mathrm{~mm}^{2}$. To reduce the limit of detection to about 2 times, the accumulation time of spectra was increased to $120 \mathrm{~s}$. The average composition of phase mixtures was calculated by 3 to 5 analyses from various areas of each section along the ingot. The error in determining the major components was 1 to 2 relation \% [18].

Some specific features of determining the composition of analyzed phases by the SEM-EDS method are noteworthy. As a result of the low-resolution ability of EDS, the peaks of Au M-series lines significantly overlap the peaks of M-series lines of heavy platinoids and K-series of sulfur. 
Unfortunately, the software of the spectrometer in this spectral region (1.9-2.5 keV) does not properly perform the deconvolution of the spectrum, which is probably due to the discrepancy between the model and the real shape of the lines. This leads to a distortion of the analysis results. Therefore, we used the L-series of radiation for these elements, though the lower LOD is 2-fold higher compared to the M-series. In this region of spectra $(9-11 \mathrm{keV})$, we also observed a significant overlapping of lines of the L-series of PGE and Au, but the effect of the deconvolution error of the spectra was much smaller. It is noteworthy that the lack of spectrometer software can lead to a false detection of sulfur in the amount of $0.8 \mathrm{wt}$. \% in gold-bearing phases, as the peak of the $\mathrm{S} \mathrm{K}_{\alpha}$ line is located on the "tail" of the $\mathrm{Au} \mathrm{M}_{\alpha}$ peak. Additional difficulties arise in the analysis of microphases, the typical size of which is smaller than the X-ray generation region. Errors in the determination of gold-bearing alloys can be related to the possible contamination of low hardness phases during preparation of the samples. These features were taken into account when processing and interpreting data.

The change in melt composition during crystallization was calculated by the formula:

$$
c_{i}^{L}=\frac{c_{i 0}-\int_{0}^{g} c_{i}^{S} d g}{1-g}
$$

Here, $g$ is the fraction of crystallized melt, $c_{i 0}$ is the concentration of the $i$-th component in the initial ingot, $c_{i}^{S}$ is the average concentration of the $i$-th component on the surface of the polished section, and the $g$ coordinate is the concentration of the $i$-th component in the melt. The obtained results were used to determine the average distribution coefficients of components between solid phases and the sulfide melt:

$$
k_{i}^{j}=c_{i}^{j} / c_{i}^{L}
$$

where $c_{i}^{j}$ is the average concentration of the $i$-th component in the $j$ phase.

\section{Results}

\subsection{Behavior of Base Components}

Visually, the ingot consists of five zones with different chemical and mineral compositions. Primary zones appeared during the successive crystallization of base metal sulfides (BMS) in accordance with the solid-liquid diagram of the system Cu-Fe-Ni-S $[6,43,44]$. On cooling of the ingot, the primary minerals completely or partially decayed to form secondary low-temperature minerals. Their sequence formed a second zonality of the crystallized ingot. The examples of microstructures in the cooled sample are shown in Figure 1.

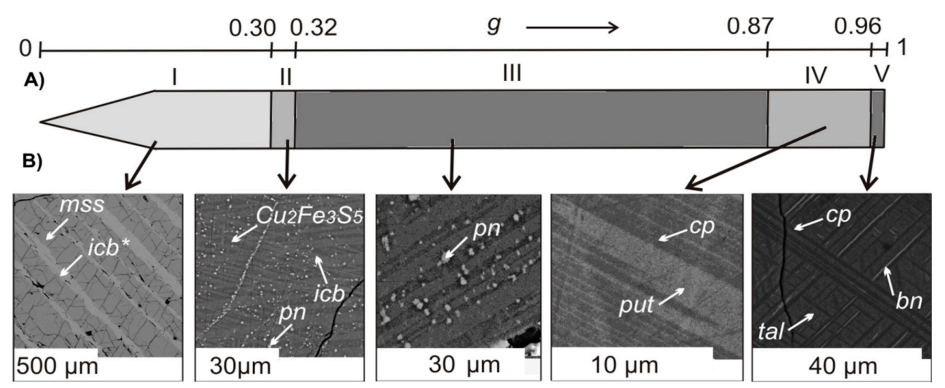

Figure 1. Structure of the directly crystallized sample. (A) Scheme of zonality. The coordinate of the process is a fraction of the crystallized melt $g$. (B) Back-scattered electron images of the polished sections belonging to different zones at $g 0.30$ (I), 0.32 (II), 0.81 (III), 0.96 (IV), and $\sim 1$ (V). Designations of phases: mss is monosulfide solid solution $\mathrm{Fe}_{43.0} \mathrm{Ni}_{2.3} \mathrm{Cu}_{1.1} \mathrm{~S}_{53.5}, i c b$ is isocubanite $\mathrm{CuFe}_{2} \mathrm{~S}_{3}$, ic $b^{*}$ is non-stoichiometric isocubanite $\mathrm{Cu}_{1.1} \mathrm{Fe}_{1.9} \mathrm{~S}_{3}, p n$ is pentlandite $(\mathrm{Fe}, \mathrm{Ni})_{9} \mathrm{~S}_{8}, c p$ is chalcopyrite $\mathrm{CuFeS}_{2}$, put is putoranite $(\mathrm{Cu}, \mathrm{Ni})_{1.1} \mathrm{Fe}_{1} \mathrm{~S}_{2}$, tal is talnakhite $(\mathrm{Cu}, \mathrm{Ni})_{18} \mathrm{Fe}_{16} \mathrm{~S}_{32}$, bn is bornite $\mathrm{Cu}_{4.3} \mathrm{Fe}_{1.5} \mathrm{~S}_{4.2}$. 
The change in the composition of the ingot along its length is presented in Table S1. To determine the primary zonality of the sample, we constructed the distribution curves of the components along the ingot and calculated their solid/liquid distribution coefficients. Data for $\mathrm{Ni}, \mathrm{Cu}$, and $\mathrm{S}$ are shown in Figure 2. Using these data, similar curves for Fe can easily be constructed. The distribution of components in the solid ingot along the zone was described by curved segments, and at the boundary between the zones there is a gap. The dependencies of component concentrations in the melt were described by piecewise continuous curves.

(A)
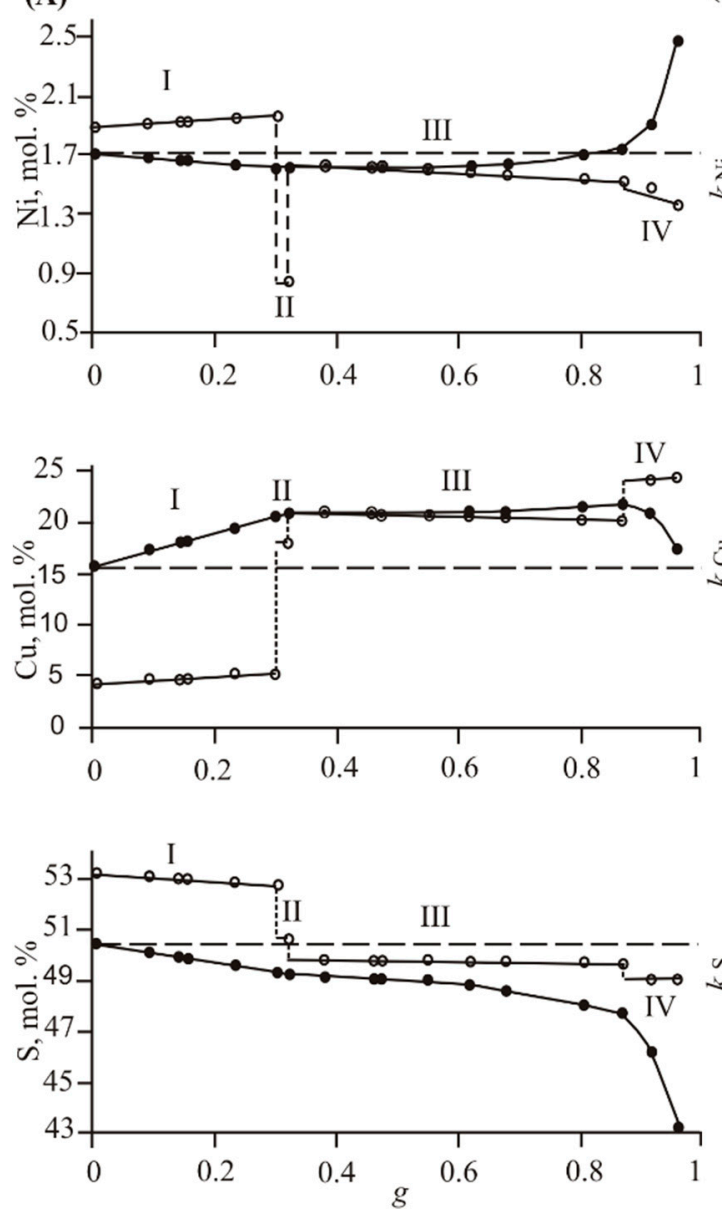

(B)
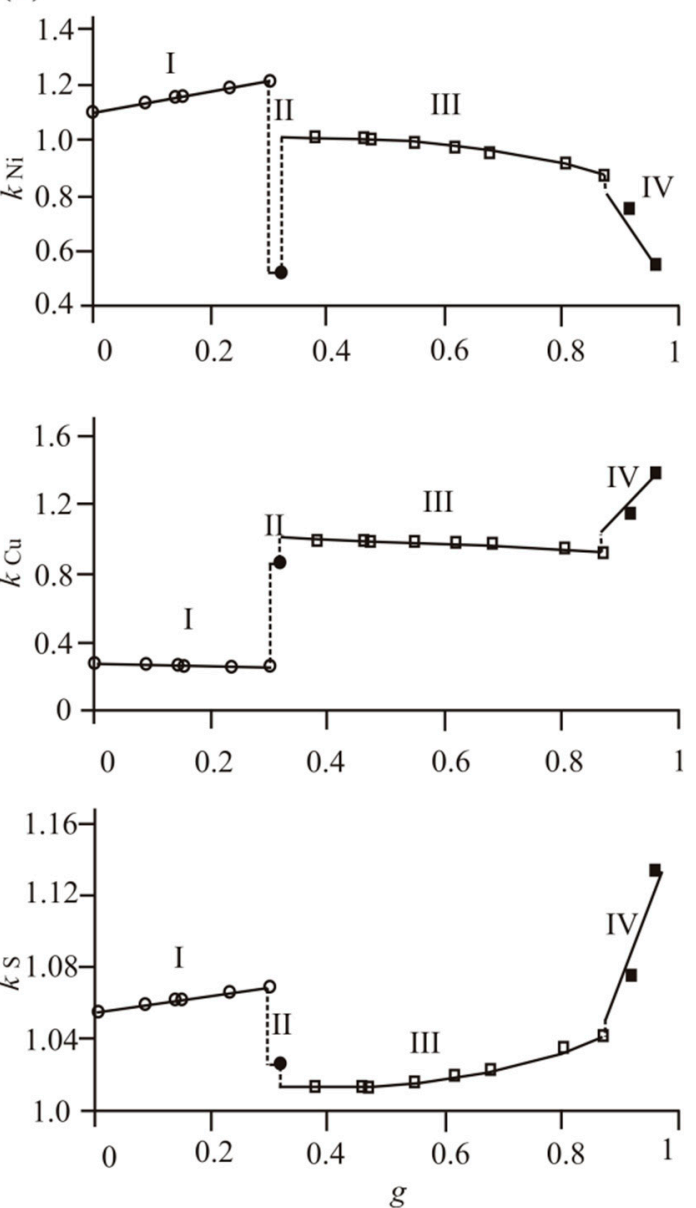

Figure 2. Primary chemical zoning of the sample. (A) Dependence of the average concentration of Ni, $\mathrm{Cu}$, and $\mathrm{S}$ in the solid sample (open circles) and in the melt (closed circles). The composition of the initial ingot is shown by a horizontal dashed line. (B) Dependence of the distribution coefficients of $\mathrm{Ni}$, $\mathrm{Cu}$, and $\mathrm{S}$ on $g$. Open circles are $\kappa(m s s / L)$, closed circles are $\kappa\left(i c b^{*} / L\right)$, open squares are $\kappa\left(i s s_{1} / L\right)$, and closed squares are $\kappa\left(i s s_{2} / L\right)$. Dashed vertical lines divide the zones.

The average chemical composition of the substance in zone I $(0 \leq g \leq 0.3)$ varies from $\mathrm{Fe}_{40.54} \mathrm{Ni}_{1.89} \mathrm{Cu}_{4.38} \mathrm{~S}_{53.19}$ to $\mathrm{Fe}_{39.86} \mathrm{Ni}_{2.05} \mathrm{Cu}_{5.22} \mathrm{~S}_{52.87}$. These data demonstrate that a monosulfide solid solution (mss) crystallizes from the melt. During crystallization, Fe and Ni mostly pass into $m s s\left(k_{\mathrm{Fe}}=\right.$ 1.27). Sulfur has a tendency to be concentrated in the solid ingot $\left(k_{S}=1.05-1.07\right)$, and $\mathrm{Cu}$ intensely enriches the melt. $\left(k_{\mathrm{Cu}}=0.25-0.28\right)$.

Zone II $(0.3 \leq g \leq 0.32)$ occupies 2 vol. \% of the sample, but it is clearly reflected in the distribution curves (Figure 2) The average chemical composition of substance in this zone is $\mathrm{Cu}_{17.96} \mathrm{Fe}_{30.59} \mathrm{Ni}_{0.86} \mathrm{~S}_{50.58}$. It corresponds to nonstoichiometric isocubanite $\left(i c b^{*}\right)$ with an idealized formula $\mathrm{Cu}_{1.1} \mathrm{Fe}_{1.9} \mathrm{~S}_{3}$ [13]. The distribution coefficients are $k_{\mathrm{Ni}}=0.53$ and $k_{\mathrm{Cu}}=0.86$. 
Zone III $(0.32 \leq g \leq 0.87)$ occupies most of the ingot. The average composition varies from $\mathrm{Fe}_{27.62} \mathrm{Ni}_{1.65} \mathrm{Cu}_{20.90} \mathrm{~S}_{49.83}$ to $\mathrm{Fe}_{28.57} \mathrm{Ni}_{1.52} \mathrm{Cu}_{20.26} \mathrm{~S}_{49.65}$. We attributed this solution to the Ni-containing intermediate solid solution iss 1 , described by Fleet and Pan (1994). It is worth noting that different forms of the existence of iss were found in the Noril'sk ores [24]. The distribution coefficients of Ni and $\mathrm{Cu}$ are close to 1 .

The average composition of substance in zone IV $(0.87 \leq g \leq 0.96)$ $\mathrm{Fe}_{25.44-25.25} \mathrm{Ni}_{1.51-1.38} \mathrm{Cu}_{24.00-24.32} \mathrm{~S}_{49.04-49.05}$ corresponds to iss 2 . An intermediate solid solution of a similar composition is reported in [43]. During crystallization, the $i s_{2}$ melt becomes enriched with $\mathrm{Fe}\left(k_{\mathrm{Fe}}=0.82-0.68\right)$ and $\mathrm{Ni}\left(k_{\mathrm{Ni}}=0.79-0.56\right)$, and the solid phase, in $\mathrm{Cu}\left(k_{\mathrm{Cu}}=1.15-1.40\right)$ and $\mathrm{S}\left(k_{\mathrm{S}}=\right.$ $1.06-1.13)$.

The average composition of the substance in zone $\mathrm{V}(0.96 \leq g<\sim 1)$ corresponds to $\mathrm{Fe}_{23.65} \mathrm{Ni}_{2.00} \mathrm{Cu}_{26.19} \mathrm{~S}_{48.16}$. One can see that the composition of this substance is similar to iss 1 and iss 2 but is highly enriched with copper. We designated it as $i s_{3}$. This zone is small and crystallized at the very end of the ingot. This complicates the exact construction of the distribution curves in zone $\mathrm{V}$ under quasi-equilibrium conditions. This is the reason why zone $\mathrm{V}$ is not shown on the distribution curves.

The micrographs shown in Figure 1 characterize the secondary zonality of the sample. The microstructure of the sample in zone I consists of the matrix of $m s s \mathrm{Fe}_{43.0 \pm 0.2} \mathrm{Ni}_{2.3 \pm 0.1} \mathrm{Cu}_{1.1} \pm 0.1 \mathrm{~S}_{53.5 \pm 0.1}$ and lamellar inclusions of nonstoichiometric isocubanite $\mathrm{Cu}_{1.1} \mathrm{Fe}_{1.9} \mathrm{~S}_{3}\left(i c b^{*}\right)$. On cooling, $i c b^{*}$ decomposed into a mixture of two phases. The main phase is isocubanite of stoichiometric composition (icb) with $0.4 \mathrm{~mol}$. \% Ni. Thin oriented lamellas of the second phase $\mathrm{Cu}_{3} \mathrm{Fe}_{4} \mathrm{~S}_{7.1}$ are contained in the matrix of $i c b$.

Zone II contained the exsolution products of primary $i c b^{*}$ : Oriented lamellas from $\mathrm{CuFe}_{2} \mathrm{~S}_{3}$, phases of composition similar to $\mathrm{Cu}_{2} \mathrm{Fe}_{3} \mathrm{~S}_{5}$, and small grains with a content of $\mathrm{Ni}$ of $8 \mathrm{~mol}$. \%. Most likely, these are inclusions of pentlandite $p n(\mathrm{Fe}, \mathrm{Ni})_{9} \mathrm{~S}_{8}$.

The microstructure of the sample in zone III consists of a two-lamellar phase and small light inclusions (see Figure 1). We could not determine the exact composition of the phases. The light inclusions contain $18 \mathrm{~mol}$ \% Ni and about $48 \mathrm{~mol}$ \% S. Most likely, they are pentlandite.

Zone IV is formed of exsolution products of iss 2 . It contains Ni-bearing chalcopyrite $\mathrm{Fe}_{24.1} \mathrm{Ni}_{0.8} \mathrm{Cu}_{24.6} \mathrm{~S}_{49.9}$ and putaronite $\mathrm{Fe}_{24.8} \mathrm{Ni}_{1.9} \mathrm{Cu}_{24.2} \mathrm{~S}_{49.1}$.

Exsolution products of iss $_{3}$ in zone $\mathrm{V}$ are bornite $\mathrm{Fe}_{14.5} \mathrm{Ni}_{0.2} \mathrm{Cu}_{42.2} \mathrm{~S}_{43.1}$, talnakhite $\mathrm{Fe}_{24.1} \mathrm{Ni}_{1.1} \mathrm{Cu}_{26.4} \mathrm{~S}_{48.4}$, and chalcopyrite $\mathrm{Fe}_{24.1} \mathrm{Ni}_{0.8} \mathrm{Cu}_{26.1} \mathrm{~S}_{49.0}$.

\subsection{Behavior of Microcomponents}

\subsubsection{Solid Solutions of Impurities in BMS}

During crystallization of the melt, the impurities may pass into the solid ingot in the form of solid solutions in primary BMS or form independent minerals. In the former case, the distribution of impurities between the solid and liquid is characterized by the values of the distribution coefficients $(k)$. In this work, we determined the $k$ for Rh in $m s s$ and for $\mathrm{Sn}$ in iss. The contents of other impurities in $m s s$ and in iss in our experiment were below the LOD of the EDS. It is noteworthy that in $[37,39,44-46]$, laser ablation was used to measure the distribution coefficients of $\mathrm{Pt}, \mathrm{Pd}, \mathrm{Ru}, \mathrm{Au}, \mathrm{As}, \mathrm{Te}, \mathrm{Bi}, \mathrm{Sb}, \mathrm{Sn}$, and Se between $m s s$ and melt. All of them, besides Ru, were $<1$.

Figure 3 shows the distribution curves of Rh in $m s s$ in zone I. The calculated distribution coefficient, $k_{\mathrm{Rh}}$, is $5.2 \pm 0.5$, i.e., this element is concentrated in mss. In the studies on crystallization of $m s s$ of another composition, $k_{\mathrm{Rh}}(\mathrm{mss} / \mathrm{L})$ is also greater than 1 and ranges from 1.5 to $6.6[37,44,46]$. We measured the dependence of $k_{\mathrm{Rh}}$ on melt composition in the system of Fe-Ni-S in the crystallization region of $m s s$ [47]. It was shown that the region is separated into two sites, one of them enriched with $\mathrm{Ni}, k_{\mathrm{Rh}}>1$, and in the other site, $k_{\mathrm{Rh}}<1$. 


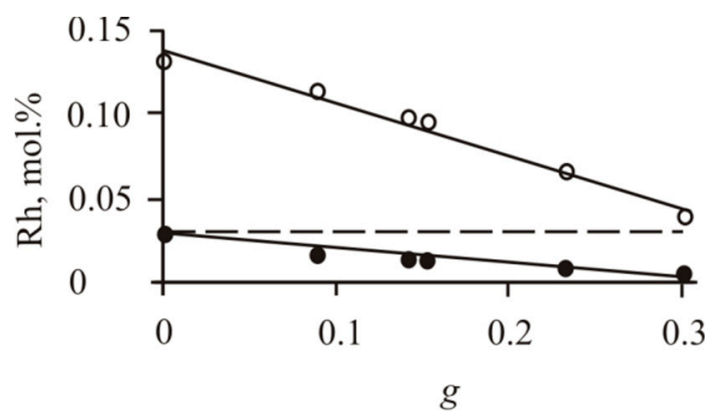

Figure 3. Distribution curves of Rh in zone I of the directly crystallized sample. Light circles correspond to the concentration of Rh в mss, and dark circles, in the melt. Dashed horizontal line shows the concentration of $\mathrm{Rh}$ in the initial melt.

The average concentration (mol. \%) of $\mathrm{Sn}$ is 0.20 in $i s s_{1}, 0.25$ in $i s s_{2}$, and 0.30 in $i s s_{3}$. Dependence of the distribution coefficient of Sn between $i s_{1}$ and melt on the fraction of crystallized melt, $g$, is shown in Figure 4.

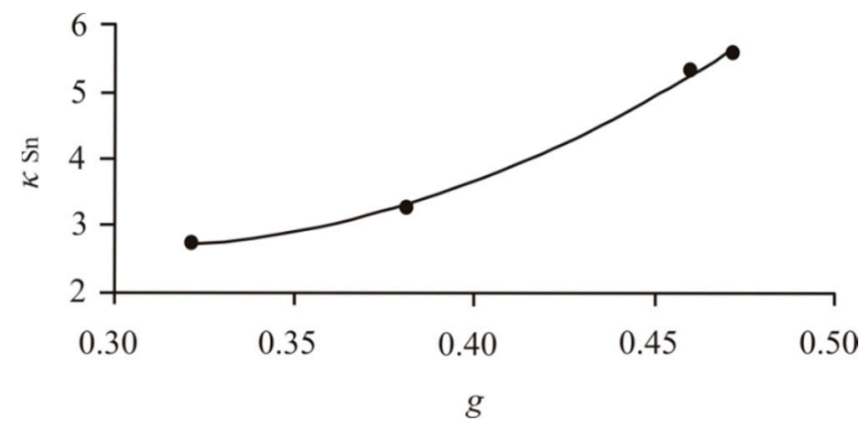

Figure 4. Dependence of the distribution coefficient of $S n$ between $i s s_{1}$ and the melt on the fraction of crystallized melt, $g$.

\subsubsection{Inclusions of Minor Phases in BMS}

The main part of the impurities is present in inclusions smaller than $\sim 100 \mu \mathrm{m}$. Most of them are formed from several phases.

Inclusions in mss (zone I): It was shown above that in zone I, a primary mss partly decomposes on cooling to form lamellas of $i c b^{*}$. Microphases are present in the matrices of $i c b^{*}, m s s$, and at the grain boundaries of $i c b^{*}$ and $m s s$, as well as on the surface of pores. We analyzed 147 single-phase inclusions. It was found that these were laurite $\mathrm{RuS}_{2}$, tsumoite BiTe, nevskite $\mathrm{Bi}(\mathrm{Se}, \mathrm{S})$, naumannite $\mathrm{Ag}_{2} \mathrm{Se}$, merenskyites $\mathrm{PdTe}_{2}$, moncheites (Pt,Pd)Te $e_{2}$, minerals of the Pt-Rh-As-S system, most likely platarsite [27], as well as two-phase intergrowths of $\mathrm{Au}^{* *}$ and (Pt,Pd) $\mathrm{Te}_{2}$ (Table S2). Typical samples of inclusions are shown in Figure 5.

Laurite $\mathrm{RuS}_{2}$ forms numerous faceted crystals $<40 \mu \mathrm{m}$ in size (Figure $5 \mathrm{~A}, \mathrm{~B}$ ). These contain about 1 mol. \% Rh and Fe. The crystals are concentrated near the sample surface. Inclusions of merenskyites, moncheites, and platarsite are present in a large number and are evenly distributed in the cross section of the sample. They have typical sizes of $<1-3 \mu \mathrm{m}$, which may lead to an increase in the inaccuracy of determining their composition. The inclusions of platinum and palladium tellurides are irregular-shaped and are associated with lamellas of $i c b^{*}$ (Figure 5C,D). Platarsite forms two types of inclusions: Weakly faceted crystals and rosettes (Figure 5G,H). It is worth noting that rosettes have the fifth-order symmetry axis, i.e., can form quasi-crystals. The number of inclusions of naumannite, nevskite, and tsumoite are small. They have a weakly faceted form and are localized in the intergranular cracks in the edge of the sample section (Figure 5B,E,F). Intergrowths of $\mathrm{Au}$ and ( $\mathrm{Pt}, \mathrm{Pd}$ ) $\mathrm{Te}_{2}$ are $<1 \mu \mathrm{m}$ in size (Figure 5I). They are localized on the surface of the pores. 


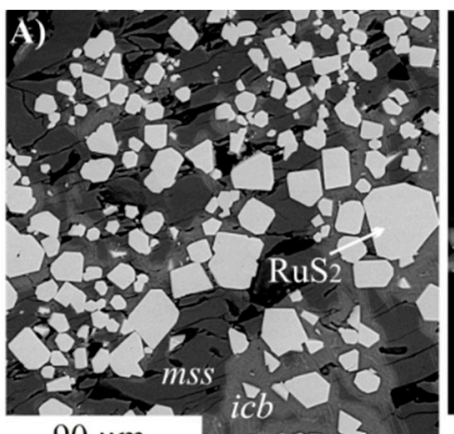

$90 \mu \mathrm{m}$
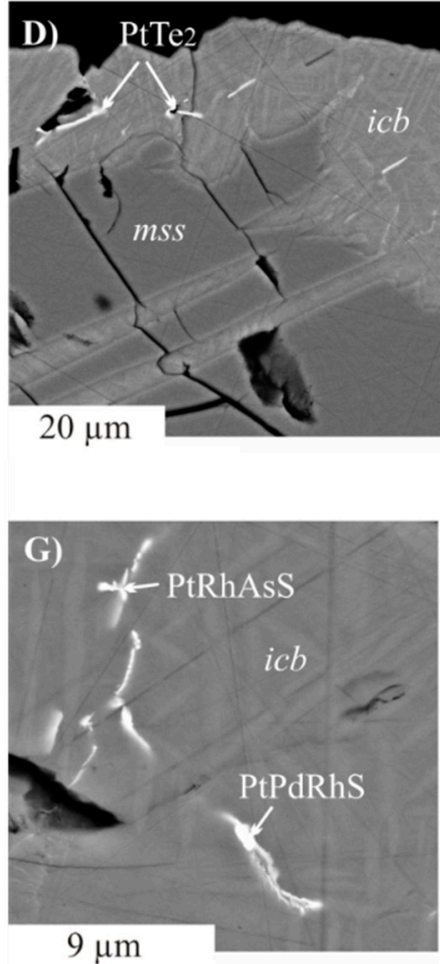

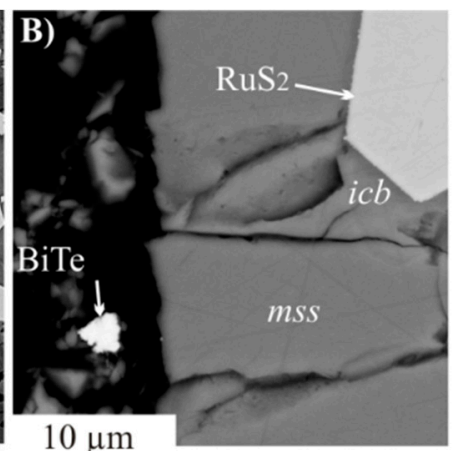

$10 \mu \mathrm{m}$

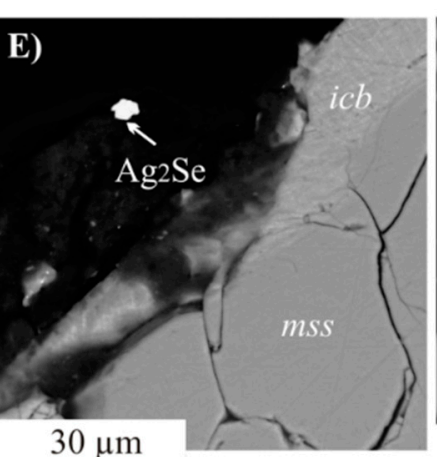

$30 \mu \mathrm{m}$
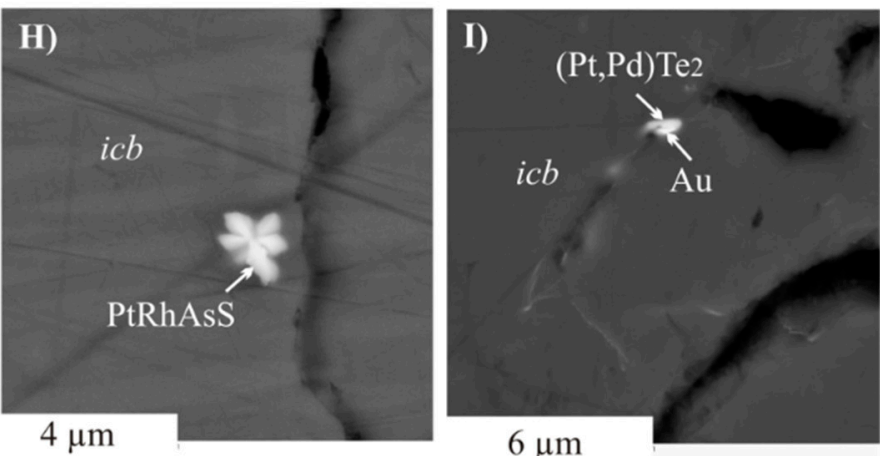

$6 \mu \mathrm{m}$
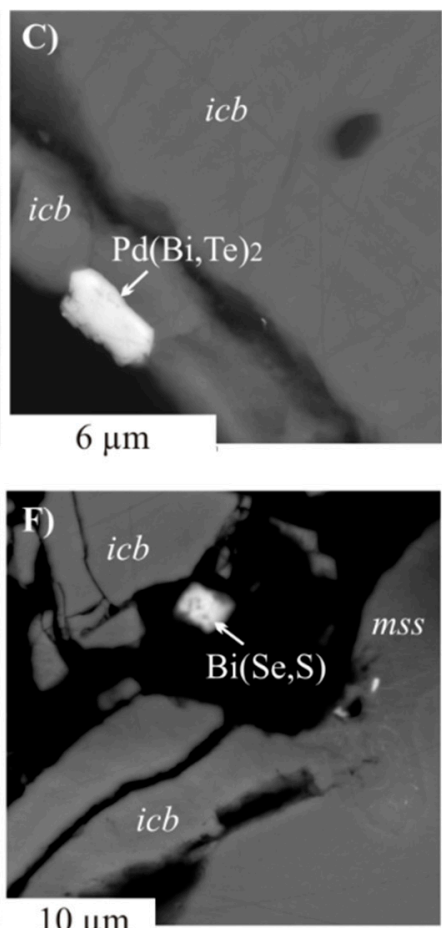

$10 \mu \mathrm{m}$

Figure 5. Back-scattered electron images of microphases in the mss zone. A primary mss partly decomposes on cooling to form lamellas of $i c b$. Microphases (bright) are present in the matrices of $i c b$, $m s s$, and at the grain boundaries of $i c b$ and $m s s$, as well as on the surface of pores. Coordinate $g$ equals $0.002(\mathbf{A}, \mathbf{B}, \mathbf{F}), 0.09(\mathbf{H}), 0.14(\mathbf{D}, \mathbf{G}), 0.15(\mathbf{C}, \mathbf{E})$, and 0.23 (I). Black is pores.

Inclusions in Fe-Cu sulfides (zones II-V): This part of the ingot is formed from $\mathrm{Fe}$ - and $\mathrm{Cu}$-rich sulfides (isocubanite, chalcopyrite, talnakhite, putoranite, bornite) and pentlandite. These zones contain numerous small $(<20 \mu \mathrm{m})$ and large (to $1 \mathrm{~mm}$ ) pores. As an example, Figure 6 shows the cross section of the sample at $g=0.38$ (zone III). The small pores are seen to be arranged in parallel rows, which is due to the specific trapping mechanism of gas bubbles, present in the sulfide melt, by a single crystal of $i s_{1}$. These rows, probably, resulted from the entrapment of bubbles by nanosteps during the layer-by-layer growth of the single crystal from the melt. Large pores are formed by another mechanism. The average size and number of pores increases to the end of the ingot.

Minor minerals form multiphase inclusions. The exception is sperrylite $\mathrm{PtAs}_{2}$ crystals, which may be present in the form of both single-phase inclusions and polyphase intergrowths. The main quantity of minor elements is concentrated in the irregular-shaped inclusions of up to $100 \mu \mathrm{m}$ in size at the interfaces (Figure 7). These inclusions were found to contain the following minerals: Sobolevskite-kotulskite solid solution $\mathrm{Pd}(\mathrm{Bi}, \mathrm{Sb})_{x} \mathrm{Te}_{1-x}$, $\mathrm{Au}$ with minor $\mathrm{Ag}, \mathrm{Cu}, \mathrm{Pd}$, hessite $\mathrm{Ag}_{2} \mathrm{Te}$, S-rich sperrylite $\mathrm{PtAs}_{2}$, wittichenite $\mathrm{Cu}_{3} \mathrm{BiS}_{3}$, stibiowittichenite $\mathrm{Cu}_{3} \mathrm{SbS}_{3}$, parkerite $\mathrm{Ni}_{3} \mathrm{Bi}_{2} \mathrm{~S}_{2}$, tetradymite 
$\mathrm{Bi}_{2} \mathrm{Te}_{2} \mathrm{~S}$, nevskite $\mathrm{Bi}(\mathrm{Se}, \mathrm{S})$, gersdorffite NiAsS, emplectite $\mathrm{CuBiS}_{2}$, and tsumoite BiTe. In addition, the matrix of BMS contains small $(\leq 20 \mu \mathrm{m})$ single multiphase drop-shaped inclusions, and faceted and non-faceted inclusions of $\mathrm{PtAs}_{2}$. The inclusions of minor minerals are also present in some pores.

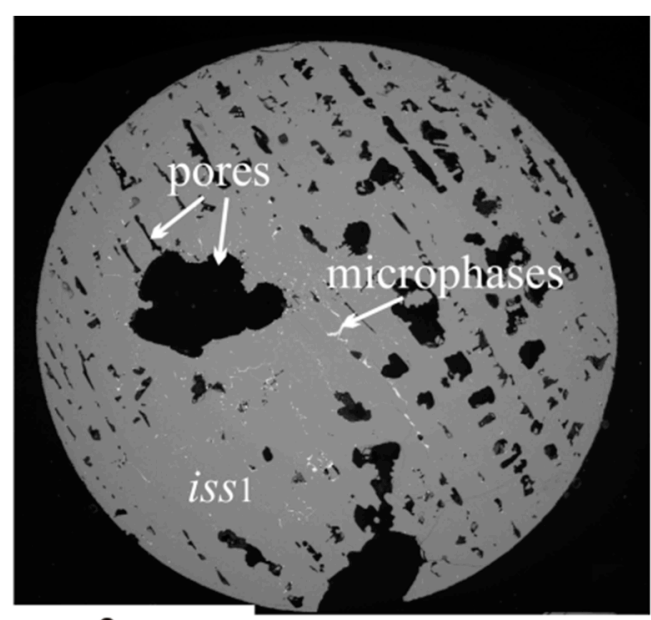

$3 \mathrm{~mm}$

Figure 6. Microphotograph of the cross section of the ingot at $g=0.38$. Light-gray matrix consists of iss ${ }_{1}$. Small light inclusions are minor phases. Dark inclusions are pores.

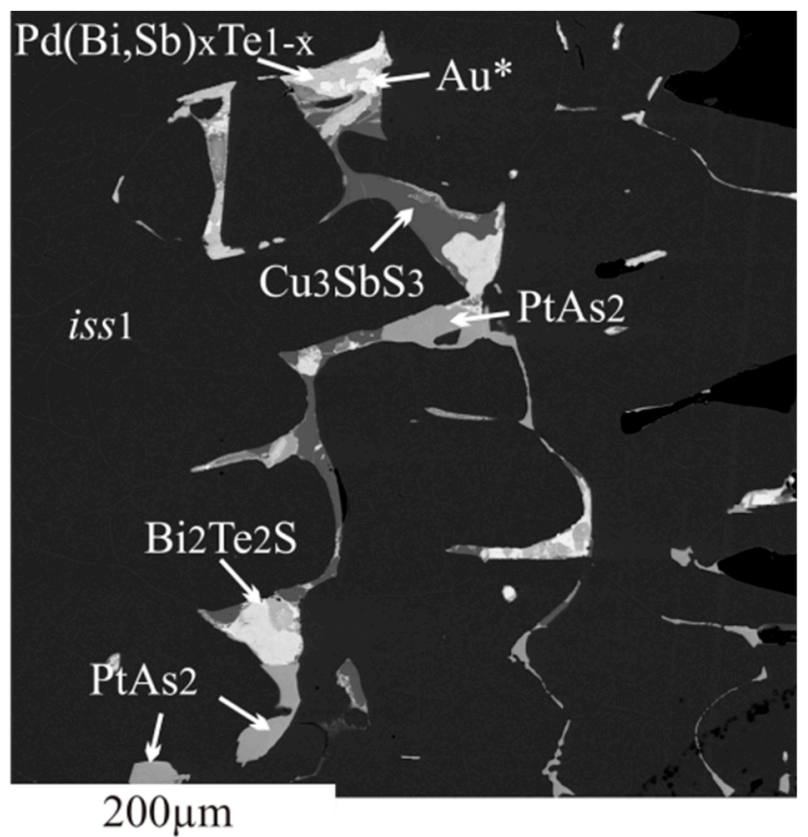

Figure 7. Backscattered electron image. The typical microstructure of the sample at $g=0.47$. Minor minerals form multiphase inclusions in the iss ${ }_{1}$ matrix. Black is pores.

Figure 8 shows the pore with multiphase inclusions of minor minerals and sperrylite. It was found that the inclusions in the matrix of BMS and the inclusions associated with pores have similar chemical and mineral compositions, i.e., were formed by the same mechanism. 


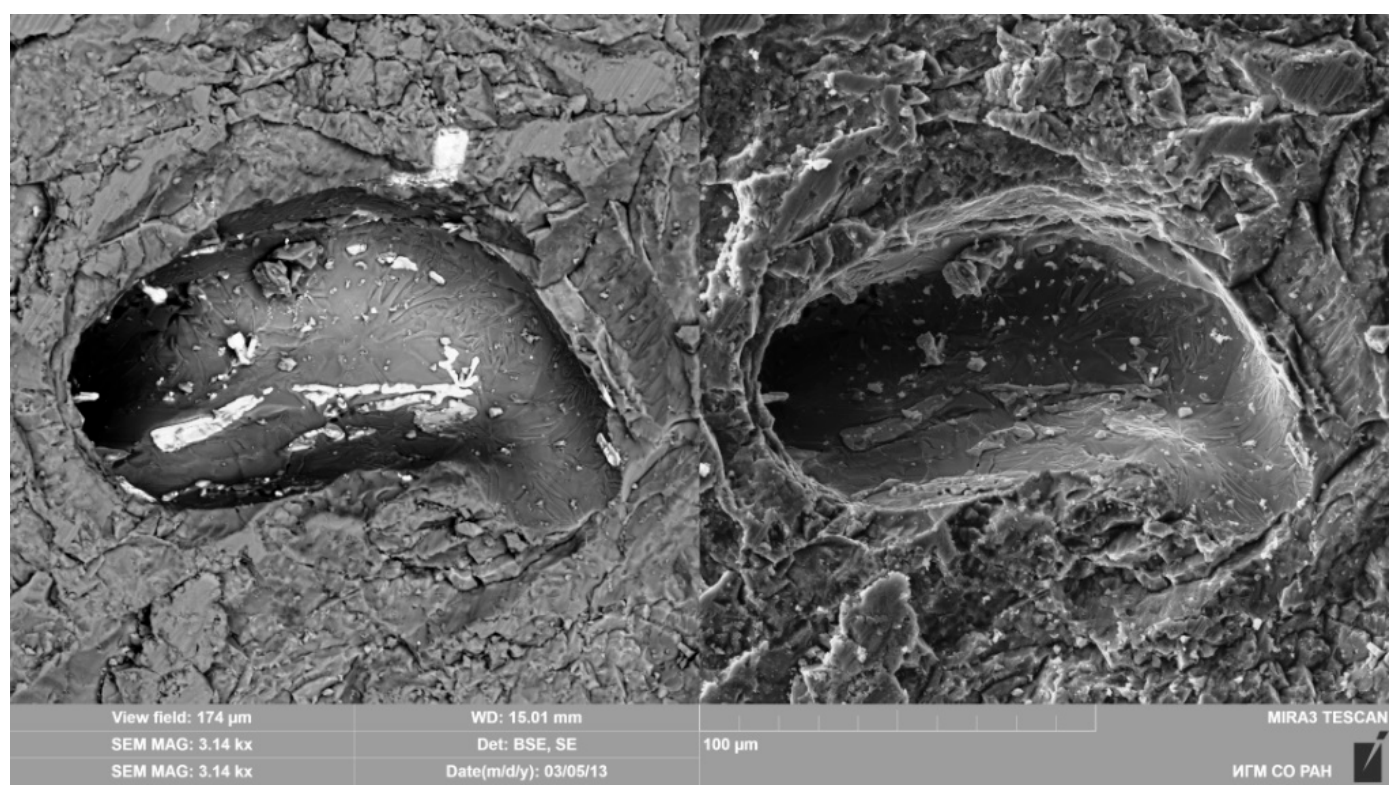

Figure 8. Microphotograph of the cleavage surface of the sample from zone II at $g=0.3$ in reflected electrons on the left and in secondary electrons on the right. There are inclusions of microphases in the gas cavity.

In the matrixes of BMS, there are a great number of drop-shaped multiphase inclusions (of oval and irregular shape with a smooth contour). We analyzed 132 inclusions and divided them into three classes according to their chemical and phase composition: 39 inclusions of class I, 21 of class II, and 72 of class III. Examples of microstructures are shown in Figures 9-11. The phase and chemical compositions are described in Tables S2 and S3.
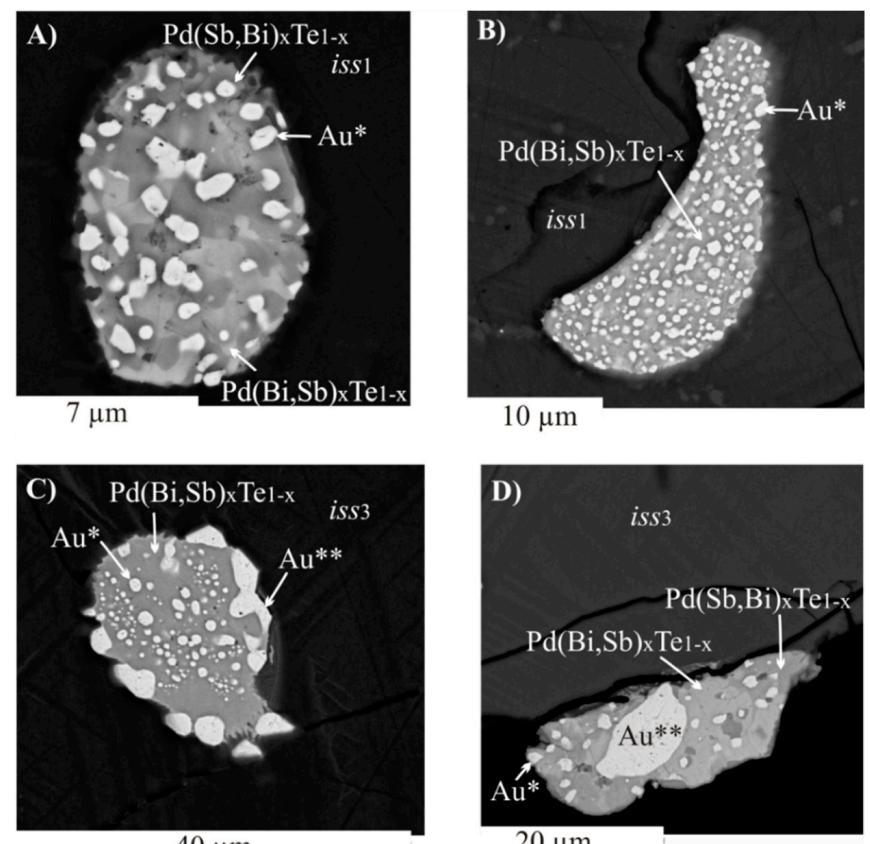

Figure 9. Backscattered electron images of the typical microphases of class I inclusions, located in the matrix of iss 1 (A,B) and iss3 (C,D). Drop-shaped inclusions consist of sobolevskite-kotulskite solid solution $\mathrm{Pd}(\mathrm{Bi}, \mathrm{Sb})_{\mathrm{x}} \mathrm{Te}_{1-\mathrm{x}}$ and $\mathrm{Au}$ alloys $\left(\mathrm{Au}^{*}\right.$ and $\left.\mathrm{Au}^{* *}\right)$. 


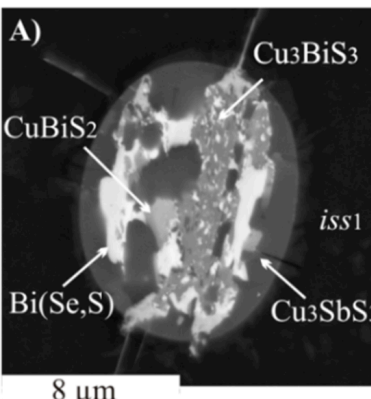

$8 \mu \mathrm{m}$

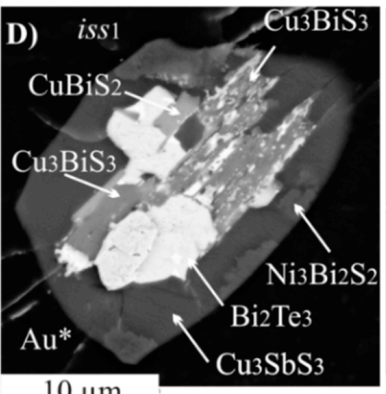

$10 \mu \mathrm{m}$

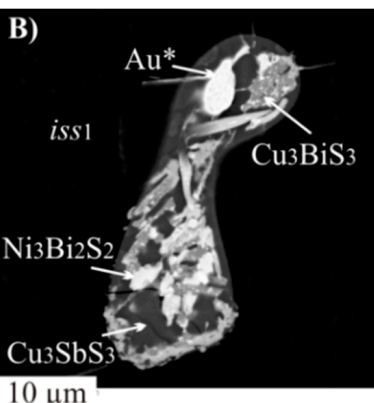

$10 \mu \mathrm{m}$

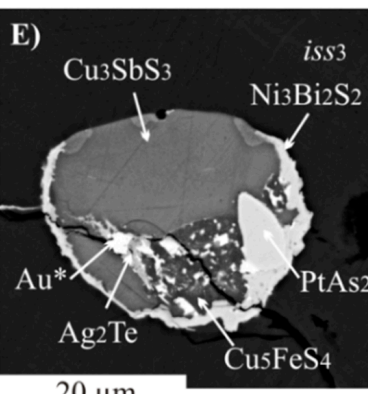

$20 \mu \mathrm{m}$
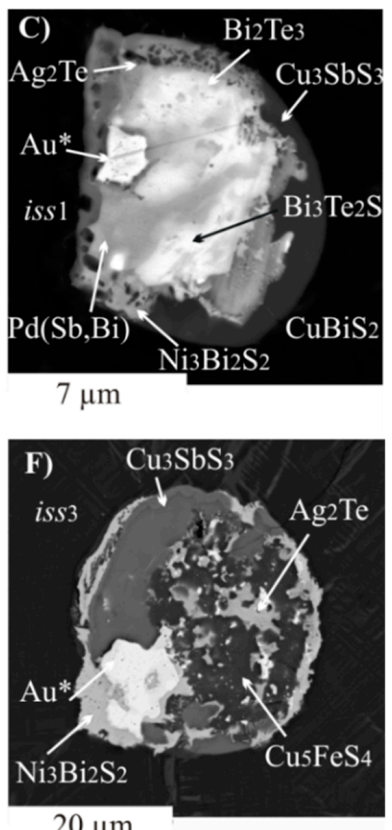

Figure 10. Backscattered electron images. Typical microstructure of class II polyphase inclusions, located in the matrix of iss 1 (B-D) and iss $3(\mathbf{A}, \mathbf{E}, \mathbf{F})$. Drop shape or more complicated shape inclusions consist of $\mathrm{Cu}_{3} \mathrm{BiS}_{3}, \mathrm{Cu}_{3} \mathrm{SbS}_{3}, \mathrm{Bi}(\mathrm{Se}, \mathrm{S}), \mathrm{Ni}_{3} \mathrm{Bi}_{2} \mathrm{~S}_{2}$, and $\mathrm{CuBiS}_{2}$ sulfosalts. Inside the inclusions $\mathrm{Au}^{*}, \mathrm{Ag}_{2} \mathrm{Te}$, $\mathrm{Bi}$, and fine-dispersed unknown phases occur.
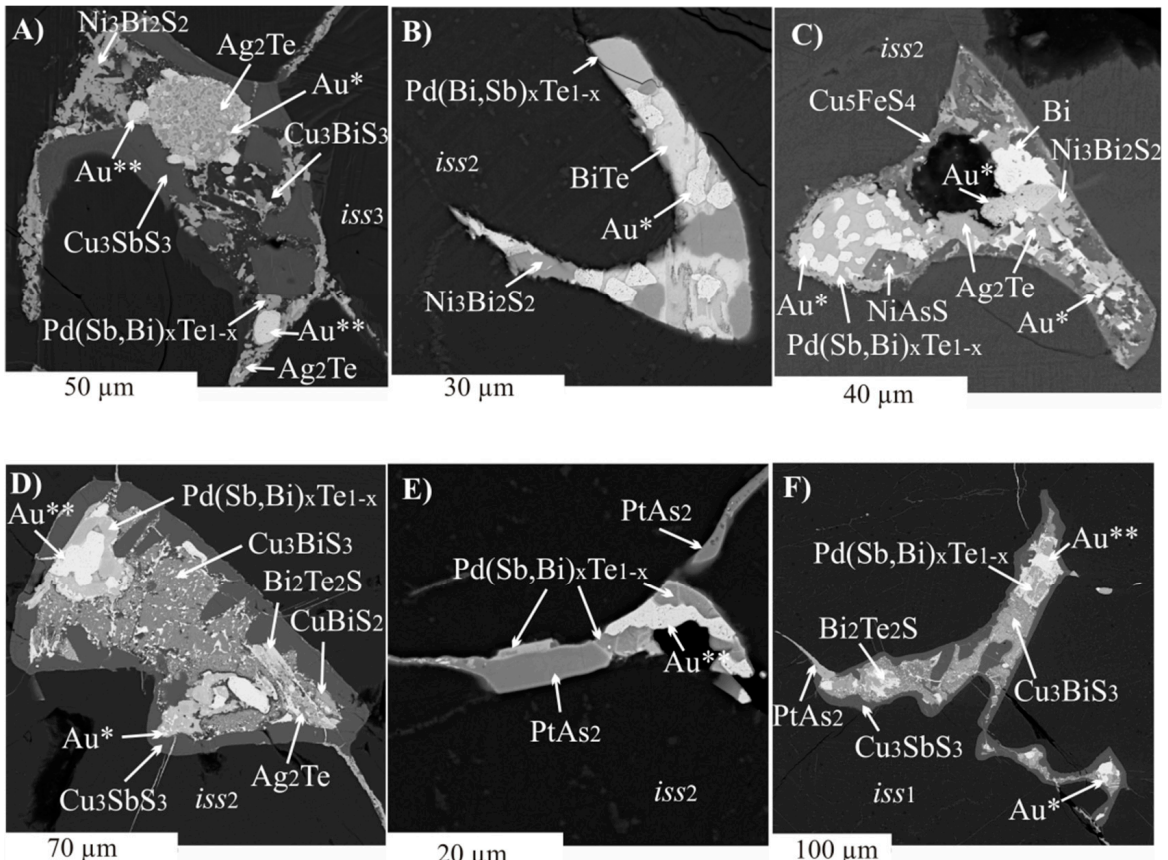

Figure 11. Backscattered electron images. Typical structure of composite inclusions of class III in iss 3 (A), iss 2 (B-E), and $i s s_{1}(\mathbf{F})$. Class III contains composite inclusions from the fragments of I and II classes and refractory microcrystals of $\mathrm{PtAs}_{2}$.

Class I. The matrix of inclusions was formed from sobolevskite-kotulskite solid solution $\mathrm{Pd}(\mathrm{Bi}, \mathrm{Sb})_{x} \mathrm{Te}_{1-x}$ described in $[27,48]$. When cooled, the solution separates into phases on the basis of sobolevskite PdTe and kotulskite PdBi (Figure 9). This two-phase matrix contains numerous inclusions $\leq 1 \mu \mathrm{m}$ in size from Au alloy ( $\mathrm{Au}^{*}, 84 \mathrm{wt}$. \% Au) (Table S2). The structure in Figure 9A,B was, most likely, formed during eutectic crystallization. The drop-shaped inclusion in Figure $9 \mathrm{C}$ has the same 
composition and structure as in Figure 9A,B. However, on its surface, large (3-5 $\mu \mathrm{m})$ crystals of high-fineness $\mathrm{Au}$ alloy $\left(\mathrm{Au}^{* *}, 97 \mathrm{wt}\right.$ \% $\mathrm{Au}$ ) are localized. The melting temperature $\left(T_{\mathrm{m}}\right)$ of $\mathrm{Au}^{* *}$ is higher than that of $\mathrm{Au}^{*}$. Figure 9D shows another type of inclusion: $\mathrm{Au}^{* *}$ crystal of $\sim 10 \mu \mathrm{m}$ in size has two neighboring drop-shaped inclusions.

Determination of the average chemical composition showed that the inclusions of class I do not contain $\mathrm{S}$ and concentrates of Pd, Au, and Ag (Table S3).

Class II. The examples of this class of inclusions of a drop shape or a more complicated shape are shown in Figure 10. They were formed from sulfosalts with idealized formulas of $\mathrm{Cu}_{3} \mathrm{BiS}_{3}, \mathrm{Cu}_{3} \mathrm{SbS}_{3}$, $\mathrm{Bi}(\mathrm{Se}, \mathrm{S}), \mathrm{Ni}_{3} \mathrm{Bi}_{2} \mathrm{~S}_{2}$, and $\mathrm{CuBiS}_{2}$ (Table S2). Most drop-shaped inclusions are located inside the shell of $\mathrm{Cu}_{3} \mathrm{SbS}_{3}$. Frequently, whiskers were observed on the surface of the shell. Inside the inclusions, fragments of $\mathrm{Cu}_{3} \mathrm{BiS}_{3}$ with a fine-dispersed unknown phase, $\mathrm{Au}^{*}, \mathrm{Ag}_{2} \mathrm{Te}$, and $\mathrm{Bi}$, occurs.

The inclusions of class II contain a large amount of $\mathrm{S}$ and $\mathrm{Cu}$ and minor quantities of $\mathrm{Sb}$ and $\mathrm{Te}$. Moreover, they contain minor silver and gold and lack Pd. The average composition of inclusions of class II and their phase composition changes along the ingot (Table S3). The constancy of the average chemical composition of inclusions of classes I and II along the ingot is noteworthy.

Class III. The matrix of Fe-Cu sulfides contains compound inclusions of various shapes. Their typical sizes range from $\sim 10$ to $\sim 100 \mu \mathrm{m}$. The average composition of inclusions varies in a wide range (Table S2). The inclusions in Figure 11A-E consist of fragments that belong to classes I and II. Less frequent are inclusions consisting of combinations of $\left(\mathrm{I}+\mathrm{PtAs}_{2}\right)$ and $\left(\mathrm{I}+\mathrm{II}+\mathrm{PtAs}_{2}\right)$ (Figure 11E,F).

Let us consider in more detail the behavior of some microminerals of noble metals.

Sobolevskite-kotulskite solid solution $\mathrm{Pd}(\mathrm{Bi}, \mathrm{Sb})_{x} \mathrm{Te}_{1-x}$ is the main concentrator of $\mathrm{Pd}$. This phase together with $\mathrm{Au}^{*}$ and $\mathrm{Au}^{* *}$ forms, most likely, the eutectic-like structure. It is typical of drop-shaped inclusions of class I. The composition of solid solution varies in a wide range: Pd from 30 to $44 \mathrm{~mol} . \%$, Bi from 3 to $20 \mathrm{~mol}$. \%, Sb from 11 to $29 \mathrm{~mol}$. \%, and Te from 8 to $38 \mathrm{~mol}$ \%. The systems of Pd-Te-Bi and $\mathrm{Pd}-\mathrm{Te}-\mathrm{Sb}$ contain continuous regions of solid solutions between PdTe-PdBi and PdTe-PdSb [27,36,48].

The Au alloys are presented in drop-shaped inclusions as numerous non-faceted or weakly faceted crystallites ranging from $<1$ to $\sim 10 \mu \mathrm{m}$ in size in the matrix of $\mathrm{Pd}(\mathrm{Bi}, \mathrm{Sb})_{x} \mathrm{Te}_{1-x}$. Analysis showed that the content of Ag in Au alloys ranges from 3.2 to 18.0 mol. \%. Additionally, Au can dissolve copper (4.3-7.6 mol. \%) and palladium (0.8 mol. \%) (Table S2). These results are consistent with the state diagrams of binary systems, $\mathrm{Au}-\mathrm{Ag}, \mathrm{Au}-\mathrm{Cu}$, and $\mathrm{Au}-\mathrm{Pd}$, and the ternary system, $\mathrm{Au}-\mathrm{Ag}-\mathrm{Cu}$, whose phase diagrams show the presence of wide regions of solid solutions $[49,50]$.

Hessite $\mathrm{Ag}_{2} \mathrm{Te}$ is associated mainly with sulfosalts in the inclusions of classes II and III. It is worth noting that in the Ag-Te system, tellurium-rich phases with low melting temperatures are also present [49].

S-rich sperrylite is the main Pt carrier in the crystallized sample. It is the only compound that forms single-phase inclusions. Besides, it is a fragment of compound inclusions. Owing to the different genesis, these varieties differ in the content of sulfur (about 17 and $25 \mathrm{~mol}$ \% S, respectively). In addition, all inclusions contain minor contents of $\mathrm{Cu}, \mathrm{Pd}, \mathrm{Sb}$, and Bi (Table S2). High solubility of $\mathrm{S}$ in $\mathrm{PtAs}_{2}$ was found in [36].

There are more than 100 mineral types of sulfosalts (Godovikov, 1992). In our samples, the major sulfosalts are $\mathrm{Cu}_{3} \mathrm{BiS}_{3}$ and $\mathrm{Cu}_{3} \mathrm{SbS}_{3}$. Moreover, they contain $\mathrm{Ni}_{3} \mathrm{Bi}_{2} \mathrm{~S}_{2}, \mathrm{Bi}_{2} \mathrm{Te}_{2} \mathrm{~S}, \mathrm{Bi}(\mathrm{Se}, \mathrm{S}), \mathrm{NiAsS}$, and $\mathrm{CuBiS}_{2}$. The presence of other finely dispersed sulfosalts is also probable. It is noteworthy that the grains of elementary $\mathrm{Bi}$ with minor $\mathrm{Cu}, \mathrm{Fe}, \mathrm{Sb}$, and Te were observed.

\section{Discussion}

As described above, a crystallized ingot consists of five primary zones with different chemical and phase compositions: mss (zone I), ic $b^{*}$ (zone II), iss 1 (zone III), and iss $s_{2}$ (zone IV). Zone V is not described in detail. These zones are sequentially formed with a gradual decrease in the temperature of the melt. In zone I, a phase reaction proceeds with the formation of a monosulfide solid solution from the melt: $L \rightarrow$ mss. At the boundary of zones I and II, non-stoichiometric isocubanite is formed 
by reaction: $L+m s s \rightarrow i c b^{*}$. When zone III occurs, the peritectic reaction of the formation of the intermediate solid solution iss $s_{1}$ proceeds: $L+i c b^{*} \rightarrow i s s_{1}$. At the boundary between zones III and IV, $i s s_{2}$ is formed by reaction: $L+i s s_{1} \rightarrow i s s_{2}$. At the end of the ingot, $i s s_{3}$ is formed, presumably by the reaction: $L+i s s_{2} \rightarrow i s s_{3}$. We carried out differential thermal analysis studies of samples from different zones of the sample. According to these data, the onset crystallization temperature is $1025^{\circ} \mathrm{C}$ for $m s s$, $953^{\circ} \mathrm{C}$ for $i c b^{*}, 947^{\circ} \mathrm{C}$ for $i s s_{1}$, and $910{ }^{\circ} \mathrm{C}$ for $i s s_{2}$.

In the experimental samples, minor amounts of noble metals were dissolved in BMS (Rh в $m s s$, $\mathrm{Sn}$ in iss) and in other phases ( $\mathrm{Ag}$ in $\mathrm{Au}^{*}, \mathrm{Au}^{* *} ; \mathrm{Au}, \mathrm{Pt}, \mathrm{Pd}$ in $\mathrm{Bi}$ ). Such forms were observed both in Noril'sk ores and in synthetic samples $[2,4,10,18,23,26,33,34,37,51]$. However, most parts of the noble metals are present in the inclusions in the form of their own minerals-alloys and compounds with metalloid admixtures $\left(\mathrm{Au}^{*}, \mathrm{Au}^{* *}, \mathrm{PtAs}_{2}, \mathrm{Pd}(\mathrm{Bi}, \mathrm{Sb})_{x} \mathrm{Te}_{1-x}, \mathrm{Ag}_{2} \mathrm{Te}\right)$. In addition, inclusions of sulfosalts also exist that do not contain noble metals of $\mathrm{Cu}_{3} \mathrm{BiS}_{3}, \mathrm{Cu}_{3} \mathrm{SbS}_{3}, \mathrm{Ni}_{3} \mathrm{Bi}_{2} \mathrm{~S}_{2}, \mathrm{Bi}_{2} \mathrm{Te} 2 \mathrm{~S}, \mathrm{Bi}(\mathrm{Se}, \mathrm{S}), \mathrm{NiAsS}$, and $\mathrm{CuBiS}_{2}$. Using the obtained experimental data, the classification scheme of inclusions in the sample was constructed (Figure 12).

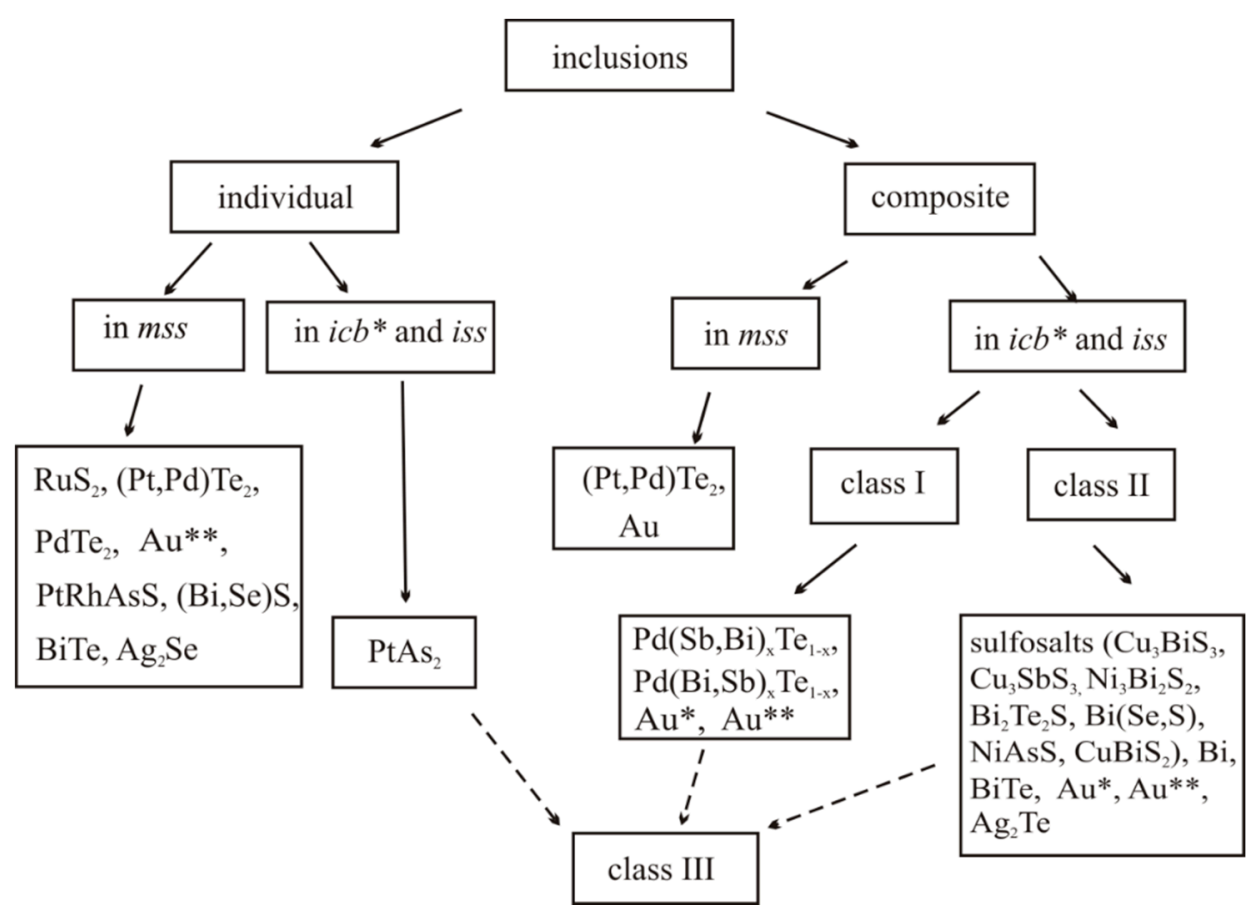

Figure 12. Classification scheme of inclusions of minor minerals.

The refractory compounds $\mathrm{RuS}_{2},(\mathrm{Pt}, \mathrm{Pd}) \mathrm{Te}_{2}, \mathrm{PtRhAsS}, \mathrm{Ag}_{2} \mathrm{Se}$, and $\mathrm{PtAs}_{2}$ have melting temperatures higher than the liquidus temperature in the $\mathrm{Cu}-\mathrm{Fe}-\mathrm{Ni}-\mathrm{S}$ system. Therefore, they crystallize in sulfide melt and then are trapped during the crystallization of BMS. The existence of two types of drop-shaped inclusions suggests that they resulted from the solidification of liquid drops of different compositions. Most likely, these drops separated as a result of the immiscibility of the parent sulfide melt with impurities.

The main amount of minor minerals is present in composite inclusions in the matrix of $\mathrm{Fe}-\mathrm{Cu}$ sulfides. The inclusions of class I are formed from a refractory $\mathrm{Au}^{*}$ that melts at $\sim 1000{ }^{\circ} \mathrm{C}$ and a low-melting $\mathrm{Pd}(\mathrm{Bi}, \mathrm{Sb})_{x} \mathrm{Te}_{1-x}$ with an estimated melting point of $<750{ }^{\circ} \mathrm{C}$ (for $\mathrm{PdTe} T_{\mathrm{m}}=746{ }^{\circ} \mathrm{C}$ [52]. It is likely that at liquidus temperatures, drops of this compound with minor $\mathrm{Au}$ are present in the sulfide melt. On cooling, these drops are trapped during the crystallization of the BMS matrix. On further cooling, gold crystals are separated from the drops, and solid inclusions are formed during the solidification of $\mathrm{Pd}(\mathrm{Bi}, \mathrm{Sb})_{x} \mathrm{Te}_{1-x}$. 
Sulfosalts of copper form low-melting crystals. For example, the temperature of incongruent decomposition of stibiowittichenite $\mathrm{Cu}_{3} \mathrm{SbS}_{3}$ is $613^{\circ} \mathrm{C}$ [53], wittichenite $\mathrm{Cu}_{3} \mathrm{BiS}_{3}$ is $535^{\circ} \mathrm{C}$ [54], and tetrahedrite is $574{ }^{\circ} \mathrm{C}$ [55]. Au, $\mathrm{Ag}$, and Te are dissolved in sulfosalt drops. On cooling, at first $\mathrm{Au}^{*}$ and $\mathrm{Ag}_{2} \mathrm{Te}\left(T_{\mathrm{m}} \sim 960^{\circ} \mathrm{C}[56]\right)$ crystallize, then sulfosalts solidify.

Class III contains composite inclusions from the fragments of I and II classes and refractory microcrystals of PtAs 2 . It can be assumed that associations of microcrystals PtAs 2 and drops I and II are in the sulfide melt. They solidify to form inclusions of class III.

The system under investigation contains $\mathrm{Au}^{*}$ and $\mathrm{Au}^{* *}$ phases, $T_{m}$ of which is above the liquidus temperature. Nevertheless, these do not form inclusions. We assume that the gold content in sulfide melt is low at liquidus temperature, and the main amount of $\mathrm{Au}$ is concentrated in liquid drops and during solidification is separated as independent phases of $\mathrm{Au}^{*}$ and $\mathrm{Au}^{* *}$.

During solidification of BMS, small droplets can be trapped on flat areas of the crystallization front. Large liquid drops can fall on the region of the crystallization front with the boundary between the crystallites. In the process of crystallite growth, the drops are trapped, and inclusions of an intricate shape are formed at interfaces (Figure 11B).

Similar inclusions of minor phases were observed in the ores from the Noril'sk and Sudbury deposits $[4,23,24,28,57-60]$ and in synthetic samples $[17,18,34,38,39,45]$. However, we did not find any results of modeling of fractional crystallization of melts with the formation of two types of PGE-metalloid liquids. Theoretical substantiation of the described phenomena is the data on the phase diagrams of binary, ternary, and more complex systems (e.g., review in [36]).

In this study, we once again demonstrated that in the directed crystallization an ingot is obtained in which phases and phase associations are spatially separated. This makes it possible to reliably and unambiguously determine the sequence of separation of primary phases during fractionation crystallization of a multicomponent sulfide melt and the change in melt composition and phase reactions when passing from one zone to another. As a result of crystallization, one can obtain a number of genetically related samples, allowing determination of the behavior of impurities at different stages of the process. It is difficult to obtain this information of phase processes by other methods. This is especially true of multiphase systems. It is worth noting that laboratory experiments imitate the continuous process of fractionation crystallization of natural sulfide liquids. Nevertheless, the methods of directional crystallization and isothermal annealing and quenching supplement each other.

Many researchers believe that the formation of massive ore bodies during fractionation crystallization takes place in the intrusive cavity in a closed system (for example, [1,2]). We modeled this process. Nowadays, there is also a hypothesis about a significant effect of hydrothermal sulfur-bearing liquids on this process (e.g., [24]). To determine the role of this or that process, additional experimental and theoretical research is necessary.

\section{Conclusions}

On the basis of our experimental data on the directed crystallization of the multicomponent $\mathrm{Cu}-\mathrm{Fe}-\mathrm{Ni}$ sulfide liquid with minor noble metals and $\mathrm{As}, \mathrm{Te}, \mathrm{Se}, \mathrm{Bi}, \mathrm{Sb}$, and $\mathrm{Sn}$, the following conclusions can be made:

1. It was shown that, in directed crystallization of melt, inclusions formed, which are similar to those observed in isothermal experiments and in sulfide ores. This is additional evidence that the minor contents of noble minerals and metalloids were present in the initial sulfide melt after its separation from the silicate melt. There is a probability of low-temperature platinum mineralization of sulfide ores as a result of hydrothermal processes but, most likely, it is realized in the aureoles of disseminated ores surrounding the massive ore bodies.

2. For the first time, simultaneous formation of two types of liquids separated during cooling of the parent sulfide melt was revealed. In the first, noble metals associated with $\mathrm{Bi}, \mathrm{Sb}$, and $\mathrm{Te}$ are concentrated. The second is related to $\mathrm{Cu}$ and contains a large amount of $\mathrm{S}$ in addition to Bi and $\mathrm{Sb}$. 
3. We established the main types of inclusions formed during fractional crystallization of Pt-bearing sulfide melt. It was shown that noble metals are concentrated in inclusions in the form of $\mathrm{RuS}_{2}$, $\mathrm{PdTe}_{2},(\mathrm{Pt}, \mathrm{Pd}) \mathrm{Te}_{2}, \mathrm{PtRhAsS}$, and $\mathrm{Ag}_{2} \mathrm{Se}, \mathrm{Au}^{* *}$ in $m s s$ and in the form of $\mathrm{PtAs}_{2}, \mathrm{Au}^{*}, \mathrm{Au}^{* *}$, and $\mathrm{Ag}_{2} \mathrm{Te}, \mathrm{Pd}(\mathrm{Bi}, \mathrm{Sb})_{x} \mathrm{Te}_{1-x}$ in $i c b^{*}$ and iss. As solid solutions in the BMS sulfides, $\mathrm{Rh}$ is present in $m s s$ and $\mathrm{Sn}$ in iss.

Thus, our experiment showed a more complex behavior of noble metals and metalloid elements during the crystallization of multicomponent sulfide-metalloid melts compared to the earlier reported data of isothermal experiments.

Supplementary Materials: The following are available online at http://www.mdpi.com/2075-163X/9/9/531/s1. Table S1: Average concentrations of components in solid phases and in the melt and distribution coefficients of components between the phases and melt, Table S2: Representative SEM/EDS analyses of microminerals, Table S3: EDS results for average composition of the inclusions.

Author Contributions: E.S. designed, performed the experiments and wrote the paper, V.K. interpreted the results and wrote the paper, G.P. performed data treatment, N.K. analyzed the compositions of phases, all the authors participated in the manuscript preparation.

Funding: This work was supported by state assignment projects of VS Institute of Geology and Mineralogy SB RAS and II.1.64.4 of Institute of Inorganic Chemistry SB RAS, financed by Ministry of Science and Higher Education of the Russian Federation. The research was partially funded by the Siberian Branch of the Russian Academy of sciences, Program of Interdisciplinary Studies, grant number 64 (project 303).

Acknowledgments: The authors thank K.A. Kokh for assistance in the experiment. We are grateful to anonymous Reviewers for their valuable comments and suggestions.

Conflicts of Interest: The authors declare no conflict of interest.

\section{References}

1. Genkin, A.D.; Distler, V.V.; Gladyshev, G.D.; Filimonova, A.A.; Evstigneeva, T.L.; Kovalenker, V.A.; Laputina, I.P.; Smirnov, A.V.; Grokhovskaya, T.L. Copper-Nickel Sulfide Ores of the Noril'sk Deposits; Nauka: Moscow, Russia, 1981; p. 234. (In Russian)

2. Distler, V.V.; Grokhovskaia, T.L.; Evstigneyeva, T.L.; Sluzhenikin, S.F.; Filimonova, A.A.; Dyuzhikov, O.A.; Laputina, I.P. Petrology of the Sulphide Magmatic Ore-Formation; Nauka: Moscow, Russia, 1988; p. 230. (In Russian)

3. Naldrett, A.J. Magmatic Sulfide Deposits: Geology, Geochemistry and Exploration; Springer: Berlin, Germany, 2004; p. 727.

4. Duran, C.J.; Barnes, S.-J.; Pleše, P.; Prašek, M.K.; Zientek, M.L.; Pagé, P. Fractional crystallization-induced variations in sulfides from the Noril'sk-Talnakh mining district (polar Siberia, Russia). Ore Geol. Rev. 2017, 90, 326-351. [CrossRef]

5. Vogt, I.H.L. Nickel in igneous rocks. Econ. Geol. 1923, 18, 307-353. [CrossRef]

6. Craig, J.R.; Kullerud, G. Phase relations in the Cu-Fe-Ni-S system and their application to magmatic ore deposits. Econ. Geol. Monogr. 1969, 4, 344-358.

7. Naldrett, A.J. Nickel sulfide deposits: Their classification, composition and genesis. Econ. Geol. 1981, 75th Anniversary, 628-685.

8. Barnes, S.-J.; Makovicky, E.; Makovicky, M.; Rose-Hansen, J.; Karup-Moller, S. Partition coefficients for Ni, Cu, $\mathrm{Pd}, \mathrm{Pt}$, $\mathrm{Rh}$, and Ir between monosulfide solid solution and sulfide liquid and the formation of compositionally zoned Ni-Cu sulfide bodies by fractional crystallization of sulfide liquid. Can. J. Earth Sci. 1997, 34, 366-374. [CrossRef]

9. Mungall, J.E.; Andrews, D.R.A.; Cabri, L.J.; Sylvester, P.J.; Tubrett, M. Partitioning of $\mathrm{Cu}, \mathrm{Ni}, \mathrm{Au}$, and platinum-group elements between monosulfide solid solution and sulfide melt under controlled oxygen and sulfur fugacities. Geochim. Cosmochim. Acta 2005, 69, 4349-4360. [CrossRef]

10. Distler, V.V. Platinum mineralization of the Noril'sk deposits. In Geology and Genesis of Platinoid Deposits; Nauka: Moscow, Russia, 1994; pp. 7-35. (In Russian)

11. Kosyakov, V.I.; Sinyakova, E.F.; Distler, V.V. Experimental simulation of phase relationships and zoning of magmatic nickel-copper sulfide ores, Russia. Geol. Ore Depos. 2012, 54, 179-208. [CrossRef] 
12. Kosyakov, V.I.; Sinyakova, E.F. Melt crystallization of $\mathrm{CuFe}_{2} \mathrm{~S}_{3}$ in the Cu-Fe-S system. J. Therm. Anal. Calorim. 2014, 115, 511-516. [CrossRef]

13. Kosyakov, V.I.; Sinyakova, E.F. Study of crystallization of nonstoichiometric isocubanite $\mathrm{Cu}_{1.1} \mathrm{Fe}_{2.0} \mathrm{~S}_{3.0}$ from melt in the system Cu-Fe-S. J. Therm. Anal. Calorim. 2017, 129, 623-628. [CrossRef]

14. Kosyakov, V.I.; Sinyakova, E.F. Experimental modeling of pentlandite-bornite ore formation. Russ. Geol. Geophys. 2017, 58, 1211-1221. [CrossRef]

15. Sinyakova, E.F.; Kosyakov, V.I. Experimental modeling of zoning in copper-nickel sulfide ores. Dokl. Earth Sci. 2007, 417A, 1380-1385. [CrossRef]

16. Sinyakova, E.F.; Kosyakov, V.I. Experimental modeling of zonality of copper-rich sulfide ores in copper-nickel deposits. Dokl. Earth Sci. 2009, 427, 787-792. [CrossRef]

17. Sinyakova, E.F.; Kosyakov, V.I. The behavior of noble-metal admixtures during fractional crystallization of As- and Co-containing Cu-Fe-Ni sulfide melts. Russ. Geol. Geophys. 2012, 53, 1055-1076. [CrossRef]

18. Sinyakova, E.; Kosyakov, V.; Distler, V.; Karmanov, N. Behavior of Pt, Pd, and Au during crystallization of Cu-rich magmatic sulfides. Can. Mineral. 2016, 54, 491-509. [CrossRef]

19. Sinyakova, E.F.; Kosyakov, V.I.; Borisenko, A.S.; Karmanov, N.S. Behavior of noble metals during fractional crystallization of $\mathrm{Cu}-\mathrm{Fe}-\mathrm{Ni}-(\mathrm{Pt}, \mathrm{Pd}, \mathrm{Rh}, \mathrm{Ir}, \mathrm{Ru}, \mathrm{Ag}, \mathrm{Au}, \mathrm{Te})$ sulfide melts. Russ. Geol. Geophys. 2019, 60, 642-651.

20. Vaulin, L.L.; Sukhanova, E.N. Oktyabr'skoe copper-nickel deposit. Razved. i Okhrana Nedr 1970, 4, 48-51. (In Russian)

21. Genkin, A.D.; Evstigneyeva, T.L. Associations of platinum-group minerals of the Noril'sk cooper-nickel sulfide ores. Econ. Geol. 1986, 81, 1203-1212. [CrossRef]

22. Distler, V.V.; Sluzhenikin, S.F.; Cabri, L.J.; Krivolutskaya, N.A.; Turovtsev, D.M.; Golovanova, T.A.; Mokhov, A.V.; Knauf, V.V.; Oleshkevich, O.I. Platinum ores of the Noril'sk layered intrusions: Magmatic and fluid concentration of noble metals. Geol. Ore Depos. 1999, 41, 241-265.

23. Barnes, S.-J.; Cox, R.A.; Zientek, M.L. Platinum-group element, gold, silver and base metal distribution in compositionally zoned sulfide droplets from the Medvezky Creek mine, Noril'sk, Russia. Contrib. Mineral. Petrol. 2006, 152, 187-200. [CrossRef]

24. Spiridonov, E.M.; Gritsenko, Y.D. Epigenetic Low-Grade Metamorphism and Co-Ni-Sb-As Mineralization in the Noril'sk Ore Field; Nauchnyi Mir: Moscow, Russia, 2009; p. 218. (In Russian)

25. Holwell, D.A.; McDonald, I. A review of the behavior of platinum group elements within natural magmatic sulfide ore systems. Platin. Met. Rev. 2010, 54, 26-36. [CrossRef]

26. Czamanske, G.K.; Kunilov, V.E.; Zientek, M.L.; Cabri, L.J.; Likchachev, A.P.; Calk, L.C.; Oscarson, R. A proton-microprobe study of magmatic sulfide ores from the Noril'sk-Talnakh district, Siberia. Can. Mineral. 1992, 30, 249-287.

27. Cabri, L.J. The Geology, Geochemistry, Mineralogy and Mineral Beneficiation of Platinum-Group Elements; Canadian Institute of Mining, Metallurgy and Petroleum: Montreal, QC, Canada, 2002; Volume 54, pp. 13-129.

28. Kozyrev, S.M.; Komarova, M.Z.; Emelina, L.N.; Oleshkevich, O.I.; Yakovleva, O.A.; Lyalinov, D.V.; Maximov, V.I. The mineralogy and behavoiur of PGM during processing of the Noril'sk-Talnakh PGE-Cu-Ni-ores. In The Geology, Geochemistry, Mineralogy and Mineral Beneficiation of Platinum-Group Elements; Canadian Institute of Mining, Metallurgy and Petroleum: Montreal, QC, Canada, 2002; Volume 54, pp. 757-775.

29. Sluzhenikin, S.; Mokhov, A. Gold and silver in PGE-Cu-Ni and PGE ores of the Noril'sk deposits, Russia. Miner. Depos. 2015, 50, 465-492. [CrossRef]

30. Peregoedova, A.; Ohnenstetter, M. Collectors of Pt, Pd and Rh in a S-poor Fe-Ni-Cu sulfide system at $760{ }^{\circ} \mathrm{C}$ : Experimental data and application to ore deposits. Can. Mineral. 2002, 40, 527-561. [CrossRef]

31. Peregoedova, A.; Barnes, S.-J.; Baker, D.R. The formation of Pt-Ir alloys and Cu-Pd-rich sulfide melts by partial desulfurization of Fe-Ni-Cu sulfides: Results of experiments and implications for natural systems. Chem. Geol. 2004, 208, 247-264. [CrossRef]

32. Peregoedova, A.; Barnes, S.-J.; Baker, D.R. An experimental study of mass transfer of platinum-group elements, gold, nickel and copper in sulfur-dominated vapor at magmatic temperatures. Chem. Geol. 2006, 235, 59-75. [CrossRef]

33. Distler, V.V.; Sinyakova, E.F.; Kosyakov, V.I. Behavior of noble metals upon fractional crystallization of copper-rich sulfide melts. Dokl. Earth Sci. 2016, 469, 811-814. [CrossRef] 
34. Cafagna, F.; Jugo, P.J. An experimental study on the geochemical behavior of highly siderophile elements (HSE) and metalloids (As, Se, Sb, Te, Bi) in a mss-iss-pyrite system at $650{ }^{\circ} \mathrm{C}$ : A possible magmatic origin for Co-HSE-bearing pyrite and the role of metalloid-rich phases in the fractionation of HSE. Geochim. Cosmochim. Acta 2016, 178, 233-258.

35. Bai, L.; Barnes, S.-J.; Baker, D.R. Sperrylite saturation in magmatic sulfide melts: Implications for formation of PGE-bearing arsenides and sulfarsenides. Am. Mineral. 2017, 102, 966-974. [CrossRef]

36. Makovicky, E. Ternary and quaternary phase systems with PGE. In The Geology, Geochemistry, Mineralogy and Mineral Beneficiation of Platinum-Group Elements; Canadian Institute of Mining, Metallurgy and Petroleum: Montreal, QC, Canada, 2002; Volume 54, pp. 131-175.

37. Ballhaus, C.; Tredoux, M.; Spath, A. Phase relations in the Fe-Ni-Cu-PGE-S system at magmatic temperature and application to massive sulphide ores of the sudbury igneous complex. J. Petrol. 2001, 42, 1911-1926. [CrossRef]

38. Helmy, H.M.; Ballhaus, C.; Berndt, J.; Bockrath, C.; Wohlgemuth-Ueberwasser, C. Formation of Pt, Pd and Ni tellurides: Experiments in sulfide-telluride systems. Contrib. Mineral. Petrol. 2007, 153, 557-591. [CrossRef]

39. Helmy, H.M.; Ballhaus, C.; Fonseca, R.O.C.; Wirth, R.; Nagel, T.J.; Tredoux, M. Noble metal nanoclusters and nanoparticles precede mineral formation in magmatic sulfide melts. Nat. Commun. 2013, 4. [CrossRef] [PubMed]

40. Karup-Moller, S.; Makovicky, E.; Barnes, S.-J. The metal-rich portions of the phase system Cu-Fe-Pd-S at 1000 ${ }^{\circ} \mathrm{C}, 900{ }^{\circ} \mathrm{C}$ and $725^{\circ} \mathrm{C}$ : Implications for mineralization in the Skaergaard intrusion. Mineral. Mag. 2008, 72, 941-951. [CrossRef]

41. Vymazalova, A.; Laufek, F.; Kristavchuk, A.V.; Drabek, M. The system Ag-Pd-Te phase relation and mineral assemblages. Mineral. Mag. 2015, 79, 1813-1832. [CrossRef]

42. Sinyakova, E.F.; Kosyakov, V.I.; Borisenko, A.S. Effect of the presence of As, Bi, and Te on the behavior of $\mathrm{Pt}$ metals during fractionation crystallization of sulfide magma. Dokl. Earth Sci. 2017, 477, 1422-1425. [CrossRef]

43. Fleet, M.E.; Pan, Y. Fractional crystallization of anhydrous sulfide liquid in the system Fe-Ni-Cu-S, with application to magmatic sulfide deposits. Geochim. Cosmochim. Acta 1994, 58, 3369-3377. [CrossRef]

44. Ebel, D.S.; Naldrett, A.J. Crystallization of sulfide liquids and interpretation of ore composition. Can. J. Earth Sci. 1997, 34, 352-365. [CrossRef]

45. Helmy, H.M.; Ballhaus, C.; Wohlgemuth-Ueberwasser, C.; Fonseca, R.O.C.; Laurenz, V. Partitioning of Se, $\mathrm{As}, \mathrm{Sb}, \mathrm{Te}$ and Bi between monosulfide solid solution and sulfide melt-Application to magmatic sulfide deposits. Geochim. Cosmochim. Acta 2010, 74, 6174-6179. [CrossRef]

46. Liu, Y.; Brenan, J. Partitioning of platinum-group elements (PGE) and chalcogens (Se, Te, As, Sb, Bi) between monosulfide-solid solution (MSS), intermediate solid solution (ISS) and sulfide liquid at controlled $f \mathrm{O} 2-f \mathrm{~S} 2$ conditions. Geochim. Cosmochim. Acta 2015, 159, 139-161. [CrossRef]

47. Sinyakova, E.F.; Kosyakov, V.I.; Nenashev, B.G. Coefficients of rhodium partition between melt and monosulfide solid solution during directional crystallization of melt in the Fe-FeS-NiS-Ni system. Dokl. Earth Sci. 2004, 397, 649-653.

48. Cook, N.J.; Ciobanu, L.; Merkle, R.K.W.; Bernhardt, H.-J. New data on sobolevskite, taimyrite and Pt ${ }_{2} \mathrm{CuFe}$ (tulameenite?) in complex massive talnakhite ore, Noril'sk orefield, Russia. Can. Mineral. 2002, 40, 329-340. [CrossRef]

49. Massalski, T.B.; Okamoto, H.; Subramanian, P.R.; Kacprzak, L. Binary Alloy Phase Diagrams, 2nd ed.; ASM International, Materials Park: Novelty, OH, USA, 1990; p. 3242.

50. Effenberg, G.; Ilyenko, S. Ternary alloy systems. Noble metal systems. Selected systems from Ag-Al-Zn to Rh-Ru-Sc, Landolf-Börnstein-Group IV. Phys. Chem. 2006, 11B. [CrossRef]

51. Barnes, S.-J.; Ripley, E.M. Highly siderophile and strongly chalcophile elements in magmatic ore deposits. Rev. Mineral. Geochem. 2016, 81, 725-774. [CrossRef]

52. Okamoto, H. Pd-Te (Palladium-Tellurium). J. Phase Equilibria Diffus. 2013, 34, 72-73. [CrossRef]

53. Ilyasheva, N.A. Study of the $\mathrm{Cu}_{2} \mathrm{~S}-\mathrm{Sb}_{2} \mathrm{~S}_{3}$ system at 320-400 ${ }^{\circ} \mathrm{C}$. Neorg. Mater. 1973, 9, 677-679.

54. Malevskii, A.Y. Study of the system Cu-Bi-S. In Proceedings of the Meeting on Experimental and Technical Mineralogy and Petrography; Nauka: Moscow, Russia, 1971; pp. 302-308. (In Russian)

55. Ilyasheva, N.A. Specific features of crystallization of tetrahedrite in the Cu-Sb-S system. Neorg. Mater. 1984, 20, 563-568. (In Russian) 
56. Krachek, F.C.; Ksanda, C.J.; Cabri, L.J. Phase relations in the silver-tellurium system. Am. Mineral. 1966, 51, 14-28.

57. Evstigneeva, T.L.; Genkin, A.D.; Kovalenker, V.A. A new bismuthide of palladium, sobolevskite, and the nomenclature of minerals of the system PdBi-PdTe-PdSb. Zapiski Vses. Mineralog. Obshch. 1975, 104, 568-579. (In Russian) [CrossRef]

58. Dare, S.A.S.; Barnes, S.-J.; Prichard, H.M.; Fisher, P.C. The timing and formation of platinum-group minerals from the Creigton Ni-Cu-Platinum-group elements sulfide deposit, Sudbury, Canada: Early crystallization of PGE-rich sulfarsenides. Econ. Geol. 2010, 105, 1071-1096. [CrossRef]

59. Dare, S.A.S.; Barnes, S.-J.; Prichard, H.M.; Fisher, P.C. Chalcophile and platinum-group element (PGE) concentrations in the sulfide minerals from the McCreedy East deposit, Sudbury, Canada, and the origin of PGE in pyrite. Miner. Depos. 2011, 46, 381-407. [CrossRef]

60. Dare, S.A.S.; Barnes, S.-J.; Prichard, H.M.; Fisher, P.C. Mineralogy and geochemistry of Cu-Rich ores from the McCreedy East Ni-Cu-PGE deposit (Sudbury, Canada): Implications for the behavior of platinum group and chalcophile elements at the end of crystallization of a sulfide liquid. Econ. Geol. 2014, 109, 343-366. [CrossRef]

(C) 2019 by the authors. Licensee MDPI, Basel, Switzerland. This article is an open access article distributed under the terms and conditions of the Creative Commons Attribution (CC BY) license (http://creativecommons.org/licenses/by/4.0/). 